\title{
Public Debts and Private Assets: Explaining Capital Flight from Sub-Saharan African Countries
}

\author{
Léonce Ndikumana and James K. Boyce \\ Department of Economics and Political Economy Research Institute \\ University of Massachusetts \\ Amherst, MA 01003
}

This Draft: August 2002

\begin{abstract}
We investigate the determinants of capital flight from 30 sub-Saharan African countries, including 24 countries classified as severely indebted low-income countries, for the period 1970-1996. The econometric analysis reveals that external borrowing is positively and significantly related to capital flight, suggesting that to a large extent capital flight is debt-fueled. We estimate that for every dollar of external borrowing in the region, roughly 80 cents flowed back as capital flight in the same year. Capital flight also exhibits a high degree of persistence in the sense that past capital flight is correlated with current and future capital flight. The growth rate differential between the African country and its OECD trading partners is negatively related to capital flight. We also explore the effects of several other factors - inflation, fiscal policy indicators, the interest rate differential, exchange rate appreciation, financial development, and indicators of the political environment and governance. We discuss the implications of the results for debt relief and for policies aimed at preventing capital flight and attracting private capital held abroad.
\end{abstract}

\section{Corresponding author:}

Léonce Ndikumana

Department of Economics

Thompson Hall, Box 37510

University of Massachusetts

Amherst, MA 01003

Email: ndiku@econs.umass.edu Web: http://www-unix.oit.umass.edu/ ndiku

Tel: (413) 545 6359; Fax: (413) 545-2921

Key words: capital flight; debt; sub-Saharan Africa; debt relief; capital control

JEL classification: F34; O16; O55;

Acknowledgements: The authors appreciate research assistance from Rachel Bouvier and Ayman Taha. We also thank Michael Ash, Carol Heim, Niels Hermes, Robert McCauley, Robert Pollin, Yiagadeesen Samy, and an anonymous referee for helpful comments and suggestions on earlier drafts of this paper. 


\title{
Public Debts and Private Assets: Explaining Capital Flight from Sub-Saharan African Countries
}

\begin{abstract}
We investigate the determinants of capital flight from 30 sub-Saharan African countries, including 24 countries classified as severely indebted low-income countries, for the period 1970-1996. The econometric analysis reveals that external borrowing is positively and significantly related to capital flight, suggesting that to a large extent capital flight is debt-fueled. We estimate that for every dollar of external borrowing in the region, roughly 80 cents flowed back as capital flight in the same year. Capital flight also exhibits a high degree of persistence in the sense that past capital flight is correlated with current and future capital flight. The growth rate differential between the African country and its OECD trading partners is negatively related to capital flight. We also explore the effects of several other factors - inflation, fiscal policy indicators, the interest rate differential, exchange rate appreciation, financial development, and indicators of the political environment and governance. We discuss the implications of the results for debt relief and for policies aimed at preventing capital flight and attracting private capital held abroad.
\end{abstract}


"Africa is suffering from multiple crises... Billions of dollars of public funds continue to be stashed away by some African leaders, even while roads are crumbling, health systems have failed, school-children have neither books nor desks nor teachers, and the phones do not work."

United Nations Secretary-General Kofi Annan (2000).

\section{INTRODUCTION}

The high level of external indebtedness is both a symptom and a cause of the poor economic performance in sub-Saharan African (SSA) countries in recent decades. In the 1990s, average debt service payments amounted to roughly $6.5 \%$ of national income in the 30 SSA countries discussed in this study. At the same time, these countries have experienced massive private outflows of funds, a phenomenon often described as "capital flight." $\square$ Recent estimates show that the region is a "net creditor" to the rest of the world in the sense that private assets held abroad as measured by accumulated capital flight exceed total liabilities as measured by the stock of debt (Boyce and Ndikumana 2001). The existing evidence also indicates that compared to other developing regions, SSA has a larger share of private wealth held abroad (Collier, Hoeffler, and Pattillo 2001). For these reasons, it is important to examine the causes of capital flight from the region.

This study investigates the determinants of capital flight from 30 SSA countries for the period 1970-1996. For this purpose we use estimates of capital flight reported by Boyce and Ndikumana (2001) for 24 countries that are classified as severely indebted low-income countries (SILICs), plus comparable estimates for six other SSA countries. ${ }^{\square}$ The estimates of capital flight are obtained using a modified version of the "residual" 
method, which is based on the difference between inflows of foreign exchange and the recorded uses of foreign exchange. Our econometric results indicate that foreign borrowing is positively and significantly related to capital flight, and that to a substantial extent capital flight is debt-fueled. Capital flight also exhibits a high degree of persistence, in that past capital flight is correlated with current and future capital flight. The growth rate differential between the African country and its OECD trading partners is negatively related to capital flight, as is an index of voice and accountability.

These results have important implications for debt relief and for policies aimed at addressing the problem of capital flight from African countries. The use of foreign borrowing to finance the accumulation of private external assets raises the questions as to the legal and moral legitimacy of the external debt - that is, its treatment as a public obligation as opposed to a private liability. Debt relief will bring sustainable benefits to African people only if it is accompanied by strategies designed to prevent a new cycle of external borrowing and capital flight in the post-relief period. These strategies must involve enforcing responsible lending practices on the part of creditors and transparent and accountable debt management on the part of African governments. At the same time, the success of African countries in preventing further capital flight and in attracting private capital held abroad will depend on their success in implementing policies that promote economic growth and a stable macroeconomic environment. 


\section{LITERATURE REVIEW}

\section{(a) Capital flight from indebted countries: a paradox?}

Developing countries have experienced simultaneously high levels of external borrowing and massive outflows of private capital. This phenomenon has been particularly notable in sub-Saharan Africa. Recent estimates indicate that compared to other regions, Africa has a larger proportion of private wealth held abroad (Collier, Hoeffler, and Pattillo 2001). At the same time, this region includes the largest number of countries defined by the World Bank as "severely indebted low-income countries"

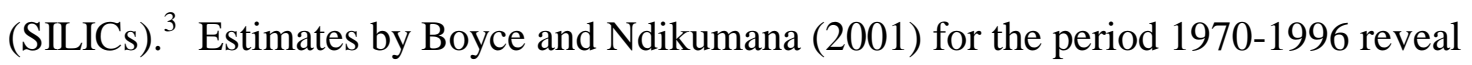
that this group of countries is a "net creditor" to the rest of the world in the sense that accumulated capital flight exceeds the stock of external debt. This poses the question of why countries borrow heavily at the same time that capital is fleeing abroad.

From a theoretical point of view, capital movements can be attributed to portfolio choice decisions by individual investors guided by profit maximization based on riskadjusted returns to capital. In a world of complete information and negligible transactions costs, the rates of return to capital would be expected to equalize across countries and markets, so that agents are indifferent between investing domestically and investing abroad. In such a world, evidence of systematic capital outflows would imply that returns to capital are systematically higher abroad than at home. Following the logic of diminishing returns, the rate of return to capital should be higher in capital-scarce developing countries than in richer countries, and capital should flow from the latter 
towards the former. If investment is riskier in developing countries, the net risk-adjusted returns may be lower, and this could explain why capital continues to flow in the opposite direction. But if the risky environment discourages domestic investment, it might be expected to discourage investment by foreigners as well. The question, as Pastor (1990: 7) puts it, is "if the investment climate in a country is negative enough to push out local capital, why would savvy international bankers extend their own capital in the form of loans?"

The literature on capital flight has offered a range of explanations for this apparent paradox in international capital movements. One set of explanations focuses on asymmetric risks of expropriation of domestic and foreign assets (Khan and Haque 1985; Cuddington 1986). Domestic agents are assumed to face a risk of government expropriation of their assets, while foreign capital is guaranteed against this risk by the debtor government and/or by international institutions. Risk asymmetry could also arise from differential tax treatment of domestic and foreign assets. In such a context, private agents maximize portfolio gains by investing abroad, even as foreign lenders find it profitable to issue loans, so that capital flight and foreign borrowing occur simultaneously. Alesina and Tabellini (1989) add political economy considerations to this explanation, suggesting that the incumbent government is happy to accumulate foreign debt since it does not internalize the burden that this will place on future (possibly rival) regimes and on future generations. 
A second set of explanations posits direct causal links between capital flight and external debt. The causal relationships can run both ways; that is, foreign borrowing can cause capital flight, while at the same time capital flight can lead to more foreign borrowing. Boyce (1992) distinguishes four possible causal links. In the first, foreign borrowing causes capital flight by contributing to an increased likelihood of a debt crisis, worsening macroeconomic conditions, and the deterioration of the general investment climate. In such cases of debt-driven capital flight, "capital flees a country in response to economic circumstances attributable to the external debt itself” (Boyce 1992: 337). In the second, foreign borrowing provides the resources as well as a motive for channeling private capital abroad, a phenomenon Boyce (1992: 338) terms debt-fueled capital flight. In such cases, funds borrowed abroad (by the government or by private borrowers with government guarantees) are re-exported as private assets. In some cases, the funds may never even leave the creditor bank, simply being transferred into an international private banking account at the same institution (Henry 1986). In the other two linkages, capital flight causes foreign borrowing. In the case of flight-driven external borrowing, capital flight drains national foreign exchange resources, forcing the government to borrow abroad. In the case of flight-fueled external borrowing, flight capital directly provides the resources to finance foreign loans to the same residents who export their capital, a phenomenon known as "round-tripping" or "back-to-back loans," motivated by the desire to obtain government guarantees on foreign borrowing, or by the need to devise a pretext for unexplained wealth. 
A potentially important but politically sensitive factor that seldom has been pursued seriously in the empirical analysis of capital flight is the role of embezzlement of borrowed money by government leaders. Like natural resources, foreign loans are 'lootable' resources that corrupt leaders can appropriate for private enrichment and channel abroad for safekeeping. Ndikumana and Boyce (1998) offer evidence that this was a major contributor to capital flight in the Congo (formerly known as Zaïre) under the Mobutu regime. Similarly, Boyce $(1992,1993)$ reviews evidence suggesting that this type of debt-fueled capital flight was widespread during the rule of Ferdinand Marcos in the Philippines.

Econometric analysis may be able to shed light on the relative strength of the possible linkages between external borrowing and capital flight. In the case of debtdriven capital flight, it is the stock of external debt rather than annual flows of borrowing that would be expected to have the strongest effect on annual capital flight. Similarly, flight-driven external borrowing would be mediated by the stock of foreign reserves. The phenomena of debt-fueled capital flight and flight-fueled external borrowing, on the other hand, would be expected to generate tighter year-to-year correlations between annual flows of external borrowing and capital flight.

Countries that have experienced high levels of capital flight in the recent past are likely to experience higher capital flight in subsequent years. This is due in part to the momentum created by capital flight itself. For example, for a given level of government expenditure, the presence of high capital flight may lead private agents to expect higher 
tax rates by virtue of the resulting lower tax base. The consequent decline in expected after-tax returns discourages domestic investment and induces private agents to seek higher returns abroad (Collier, Hoeffler and Pattillo 2001). Moreover, capital flight may be 'habit-forming,' making investors unlikely to respond rapidly to any improvements in the investment climate.

\section{(b) Empirical evidence on the determinants of capital flight}

There is a substantial empirical literature on the determinants of capital flight, originating in the 1980s with studies primarily on Latin American countries. Although results vary, due in part to differences in the measurement of capital flight and differences in econometric techniques and specifications, some important empirical regularities have emerged. Table 1 summarizes the main findings from a selection of 17 studies on developing countries. In what follows, we briefly discuss the factors that have been most emphasized in the literature.

\section{[INSERT TABLE 1 HERE]}

\section{Capital inflows}

The single most consistent finding in empirical studies is that the annual flow of external borrowing is an important determinant of capital flight. This relationship has been established in single-country time-series studies as well as large-sample crosssectional and pooled data studies, and it is generally robust to alternative specifications of the capital flight equation, measures of capital flight, and econometric estimation 
methodologies. These findings suggest that debt-fueled capital flight has been a widespread phenomenon. Flight-fueled external borrowing could also contribute to this result. Using an instrumental variable approach to test for possible simultaneities, Boyce $(1992,1993)$ concludes that the causal relationships ran in both directions in the Philippines.

Relatively few empirical studies have examined the impact of the stock of debt as opposed to debt flows on capital flight. As discussed above, a high debt overhang can drive capital flight by worsening the macroeconomic environment and increasing the likelihood of a debt crisis. On the other hand, a high stock of debt might also be interpreted as evidence of creditworthiness, signaling higher expected availability of foreign exchange, and thereby reducing the incentives for capital flight. Vos (1992) finds that the debt stock had no statistically significant impact on capital flight from the Philppines, while Collier, Hoeffler, and Pattillo (2001), in a cross-sectional study, report a statistically significant positive impact (that is, a higher debt stock leads to greater capital flight).

A few studies have investigated the role of other types of capital inflows as explanatory variables. Hermes and Lensink (2000) and Lensink, Hermes, and Murinde (2000) include development aid in addition to private lending, and find that it too has a positive effect, suggesting that capital flight can be fueled by grants as well as by loans. Lensink, Hermes, and Murinde (2000) also include direct foreign investment as an 
explanatory variable, and find that it has no statistically significant effect on capital flight.

Several empirical studies (Mikelsen 1991; Vos 1992) have reported a positive correlation between past capital flight and current capital flight, suggesting that capital flight tends to persist over time. This finding has been less robust, however, with some studies reporting insignificant or negative effects (Cuddington 1987; Boyce 1992; Nyoni 2000).

\section{The macroeconomic environment}

The indicators of the macroeconomic environment that have been used most frequently in empirical studies of capital flight are inflation and the growth rate of income. A high expected inflation makes assets denominated in domestic currency less attractive compared to those denominated in foreign currency. Inflation can also be regarded "as an indicator of the overall ability of the government to manage the economy" (Fischer 1993: 487). Several empirical studies have found evidence that high inflation encourages capital flight (see Table 1). Note, however, that the causality can also run in the reverse direction: as capital flight erodes the tax base, the government may resort to money creation to finance the fiscal deficit. "Inflation may be the origin of capital flight, but once it takes place it has in itself a powerful inflationary impact," Dornbusch (1987: 148) remarks. "In the end it is hard to identify which is the chicken and which is the egg." 
Empirical evidence also supports the hypothesis that capital flight is higher when a country's rate of economic growth is low. Pastor (1990) finds that the growth rate differential between the USA and Latin American countries is an important determinant of capital flight from the region. Nyoni (2000) relates capital flight from Tanzania to the growth rate differential between Tanzania and the United Kingdom, and obtains a similar

result. The empirical evidence is more mixed with regard to the effect of a country's growth rate alone on capital flight, with a number of studies finding that the effect is either not significant or not robust to alternative specifications and estimation methodologies. This may reflect the fact that economic growth is itself affected by some of the same factors that cause capital flight, making it difficult to isolate its independent effects.

None of the empirical studies reviewed here examines the ratio of exports to GDP as a possible determinant of capital flight. Yet in the case of sub-Saharan Africa, this may be a relevant feature of the macroeconomic environment. Exports not only provide a source of foreign exchange and (through underinvoicing) a mechanism for capital flight, but also often are an arena for rent-seeking activities by politically powerful parastatal and private actors, particularly in the cases of minerals and agricultural commodities.

\section{Fiscal policy}

Several studies find that government budget deficits are positively related to capital flight; that is, a higher deficit (or lower surplus) is associated with greater capital 
flight. Research on this topic is still scant in the case of sub-Saharan African economies, however, for which the only study that we have been able to identify (Hermes and Lensink 1992) finds no evidence of a statistically significant link between fiscal deficits and capital flight. This topic deserves further attention, given the chronic budget deficits that many sub-Saharan African countries have experienced over the years.

Another fiscal policy indicator that has been explored in some studies is taxation. There are three main ways in which taxation is thought to affect capital flight, apart from its effect on the fiscal balance. First, ceteris paribus, expected high tax rates imply lower expected net returns to domestic investment. Second, volatility of the tax rate results in higher investment risk and lower risk-adjusted returns to domestic investment. Third, discriminatory tax treatment in favor of foreign assets (often used to attract foreign capital) may also discourage domestic investment. Hermes and Lensink (2000) find a positive link between capital flight and uncertainty of government tax policy. ${ }^{5}$ Studies that include the tax/GDP ratio directly (as opposed to its unpredictable component) have not found a statistically significant link between taxation and capital flight (Pastor 1990; Vos 1992; Hermes and Lensink 1992), suggesting that it is the policy uncertainty of taxation that matters most for portfolio decisions.

In general, it is problematic to characterize a government's fiscal policy stance by means of a single variable such as the budget deficit or the tax rate (see MacKenzie (1989) for a survey of literature on this topic). Moreover, the quality of data on fiscal policy variables reported in international databases is often poor, especially in the case of 
developing countries. Hence, empirical evidence on the effects of fiscal policy must be interpreted cautiously.

\section{Risk and returns to investment}

Indicators of risk and returns to investment have been examined as determinants of capital flight, based on portfolio choice theory. Investors are assumed to seek to maximize profits by allocating funds between domestic and foreign investment based on the relative risk-adjusted rate of return at home and abroad. Various indicators have been used to test this theory: the interest rate differential (that is, the domestic rate minus the foreign rate), exchange rate movements, and survey-based measures of institutional investor risk perceptions. As indicated in Table 1, a number of studies have found that differential risk-adjusted returns have statistically significant effects in the expected direction. Dooley (1988), for example, finds that financial repression, characterized by artificially low domestic deposit interest rates, is an important determinant of capital flight. Studies of capital flight from African countries, however, have found no significant relationship between interest rates and the magnitude of capital flight (Hermes and Lensink 1992; Murinde, Hermes and Lensink 1996; Nyoni 2000; Ng'eno 2000).

There is also some evidence that in SSA and elsewhere exchange rate

overvaluation leads to capital flight. ${ }^{6}$ When the national currency is overvalued, the expectation that the currency will depreciate induces private investors/savers to shift their portfolio composition in favor of foreign assets (Cuddington 1986, 1987). As an alternative to the exchange rate, Olopoenia (2000) and Nyoni (2000) use the "black 
market" premium (i.e., the difference between market and official exchange rates) as an explanatory variable, but find it to have no statistically significant effect on capital flight.

Investor-based survey data also have been used to investigate the effects of risk perceptions on capital flight. Noting that risk ratings are related to other determinants of capital flight, such as macroeconomic policy uncertainty and economic performance indicators, Collier, Hoeffler, and Pattillo (2001) extract the unpredictable components of the risk ratings, and find that they do not have a significant independent effect on capital flight.

\section{Financial development}

The role of financial intermediation has received relatively little attention in the empirical literature on capital flight. In principle, financial development can reduce capital flight if accompanied by an expansion of opportunities for domestic portfolio diversification. However, financial deepening can also encourage capital flight if it facilitates international capital transfers. In particular, if financial markets are liberalized and international capital movements are deregulated, then domestic capital may be expected to flow abroad as long as risk-adjusted returns are higher elsewhere. Lensink, Hermes, and Murinde (1998) find a negative and significant effect of demand deposits on

capital flight. Using the M2/GDP ratio as a measure of financial development, $\mathrm{C}_{\mathrm{Collier}}$ Hoeffler, and Pattillo (2001) find that it has no statistically significant effect. 


\section{Political and governance factors}

A few studies have examined the effects of political and governance factors on capital flight. We would expect that political instability and poor governance would contribute to poor economic performance, high uncertainty, and a negative overall investment climate, all of which would be likely to discourage domestic investment and encourage capital flight. Empirical evidence on the direct effects of political and governance factors remains rather sparse, however. In part, this may be due to the lack of reliable measures for these factors. In large cross-sectional studies, however, Hermes and Lensik (2000) and Lensink, Hermes, and Murinde (2000) have found that holding other factors constant, political instability and war lead to greater capital flight, and that democracy and political freedom are associated with less capital flight.

\section{DATA}

The present study examines the determinants of capital flight from 30 subSaharan African countries for the period 1970-1996. Our sample includes 24 SSA countries that are classified as severely indebted low-income countries (SILICs), for which estimates of capital flight are presented by Boyce and Ndikumana (2001). In this study, we add another six SSA countries that are not classified as SILICs, but for which the necessary data to estimate capital flight are available (Benin, Gabon, Mauritius, Senegal, Togo, and Zimbabwe). The capital flight series for the 30 SSA countries is presented in Table A1 in the appendix. The panel structure of the data set, embodying both time-series and cross-country variations in capital flight and its potential 
determinants, increases the number of observations and hence the degrees of freedom compared to single-country studies. Detailed information on the definitions of variables used in the analysis and data sources is presented in Table A2. The country means of the variables are reported in Table A3.

\section{(a) Capital flight}

The empirical literature has advanced a number of approaches to measuring capital flight (for discussions, see Lessard and Williamson 1987; Vos 1992; and Ajayi 1997). The measure used in this study is derived using the methodology described by Boyce and Ndikumana (2001). For country $i$ in year $t$, capital flight is computed as follows:

$$
K F_{i t}=\Delta D E B T A D J_{i t}+D F I_{i t}-\left(C A_{i t}+\Delta R E S_{i t}\right)+M I S I N V_{i t}
$$

where $\triangle D E B T A D J$ is the change in the country's stock of external debt (adjusted for cross-currency exchange rate fluctuations, so as to take into account the fact that debt is denominated in various currencies and then aggregated in US dollars); DFI is net direct foreign investment; $C A$ is the current account deficit; $\triangle R E S$ is the change in the stock of international reserves; and MISINV is net trade misinvoicing. This is a variant of the "residual" method for the computation of capital flight, used by the World Bank (1985) among others, based on the difference between the inflows of foreign exchange from external borrowing (as reported in the World Bank's World Debt Tables) and the uses of foreign exchange reported in the IMF's Balance-of-Payments Tables. We refine this measure by incorporating adjustments for trade misinvoicing and for the impact of

exchange rate fluctuations on the dollar value of external debt. ${ }^{\mathrm{T}}$ The nominal values of 
annual capital flight are converted to real values using the US producer price index (base $1996=100)$.

Table 2 summarizes the magnitude of capital flight from SSA countries. Real capital flight over the 27 -year period amounted to about $\$ 187$ billion for the 30 countries. Including imputed interest earnings, the accumulated stock of capital flight was about $\$ 274$ billion as of end-1996. As a whole, this group of SSA countries is a "net creditor" to the rest of the world in the sense that their private assets held abroad, as measured by capital flight including interest earnings, exceed their total liabilities as measured by the stock of external debt. Their net external assets (accumulated flight capital minus accumulated external debt) amounted to approximately $\$ 85$ billion.

[INSERT TABLE 2 HERE]

The volume of capital flight varies substantially across countries. In terms of absolute magnitude, Angola, Cameroon, Côte d'Ivoire, the Democratic Republic of Congo, and Nigeria have the highest stocks of capital flight. The ratio of capital flight stock to GDP exceeds $200 \%$ for eight countries, with a weighted average ratio of $172 \%$ for the group. Five of the 30 countries (Benin, Mali, Niger, Senegal, and Togo) exhibit a "negative" stock of flight capital, indicating that their recorded capital inflows exceed recorded uses of foreign exchange.

\section{(b) Independent variables}




\section{Capital flows and stocks}

As a measure of capital inflows, we use the annual change in the total debt stock (adjusted for exchange rate fluctuations). We use the stock of debt as a measure of debt overhang.

\section{Macroeconomic environment}

As indicators of the macroeconomic environment, we use annual growth rate of real per capita GDP; the growth rate differential between the African country and the USA; the growth rate differential between the country and its OECD trading partners (weighted average by trade shares); the annual inflation rate measured by the percentage change in the consumer price index; the inflation rate differential between the country and the USA; and exports as a percentage of GDP.

\section{Fiscal policy}

As indicators of the fiscal policy we use the primary budget deficit, the overall fiscal deficit, and the tax/GDP ratio.

\section{Risk and returns to investment}

As indicators of the returns to domestic investment, we use the percentage change in the real exchange rate (index 1990=100) as an indicator of the risk associated with investing domestically; the domestic deposit rate; the spread between the domestic lending rate and the deposit rate; and the difference between the domestic deposit rate and the U.S. Treasury bill rate with an adjustment for depreciation of the local currency 
(that is, the domestic deposit rate minus the U.S. Treasury bill rate minus the percentage change in the official exchange rate).

\section{Financial development}

We use two measures of financial intermediation: the ratio of total liquid liabilities (M3) to GDP, which serves as a proxy for the size of the financial system; and credit to the private sector as a percentage of GDP, a measure of availability of credit in the domestic financial market.

\section{Governance and the political environment}

Finally, we examine the effects of five indicators of governance and the political environment: political freedom and civil liberty; voice and accountability; government

effectiveness; risk of contract repudiation; and corruption. ${ }^{10}$ The indexes of freedom, risk of contract repudiation, and corruption are available as annual time series, while the other two indexes are available as one observation per country. ${ }^{-}$For the time-variant indexes we relate capital flight to their unpredictable components, obtained as residuals from forecasting equations, on the grounds that uncertainty regarding these variables is most likely to spark capital flight.

\section{ECONOMETRIC ANALYSIS}

(a) Methodology

The existing theory does not offer a clear-cut way of determining a priori which independent variables should be included in the empirical model of the determination of 
capital flight for a particular sample of countries. Hence we follow a stepwise approach, adding explanatory variables one by one and retaining those that are statistically significant. A combination of six explanatory variables remain significant when used simultaneously: two lags of capital flight, change in debt, the lag of the debt stock, and the lag of the growth rate differential between the African country and its OECD trading partners. We refer to this as the "expanded model". The two lags of capital flight and the change in debt invariably remain significant when other variables are added to the equation one by one. In contrast, the debt stock, the growth rate differential, and other variables are not robust to addition of more regressors. We refer to the regression in which the only explanatory variables are the two lags of capital flight and the change in debt as the "base model".

The model specifications can be represented by the following equation:

$$
K F_{i t}=\alpha_{0 i}+\alpha_{1} K F_{i, t-1}+\alpha_{2} K F_{i, t-2}+\alpha_{3} C D_{i t}+\boldsymbol{\beta}^{\prime} \mathbf{X}_{i, t-1}+\boldsymbol{\delta}^{\prime} \mathbf{Z}_{i}+\varepsilon_{i t}
$$

where for a country $i$ at time $t, K F$ is the ratio of real capital flight to GDP, $C D$ is the ratio of the change in debt stock to GDP, $\mathbf{X}$ is a vector of other time-varying independent variables, $\mathbf{Z}$ is a vector of time-invariant independent variables (the two governance indicators), $\alpha_{0 i}$ is a country-specific intercept representing unobservable individual characteristics, and $\varepsilon$ is a white noise error term. To allow for country-specific fixed effects, we mean-difference all time-varying variables. 3 The regressions that include the time-invariant indicators (the index of voice and accountability and the index of government effectiveness) do not include fixed effects as these would be collinear with the time-invariant variables. 
We first run the regressions with annual panel data, an approach that not only maximizes the degrees of freedom but also allows us to analyze the dynamic effects of past capital flight through the inclusion of lagged values. In these regressions, we test and correct for serial correlation of the error term as needed, using the Cochrane-Orcutt transformation procedure (see Griffiths, Hill, and Judge 1993). As a check on the robustness of our results, we then collapse the data into a single cross-section where each country has one observation, consisting of the means of the time-varying factors and the values of the time-invariant factors. $\frac{14}{1}$

As discussed above, there may be a two-way relationship between external borrowing and capital flight. To investigate this possibility, we test for endogeneity of the change in debt $(C D)$ by estimating the following equation:

$$
K F_{i t}=\phi_{0}+\phi_{1} C D_{i t}+\xi_{i t}
$$

where $\xi$ is an error term with the standard properties. We use the Hausman (1978) test to test for endogeneity, using lagged values of change in debt and capital flight as instruments. The results indicate no statistically significant simultaneity bias. ${ }^{15}{ }_{\mathrm{We}}$ therefore retain contemporaneous change in debt in the model, a specification that allows us to examine whether capital flight is fueled by external borrowing. To address possible simultaneity problems for other time-varying independent variables, we use the first lags of these regressors in estimating equation (2). 


\section{(b) Results}

The results of the regressions using annual pooled data are reported in Tables $3 \mathrm{a}$ and $3 \mathrm{~b}$, and the results of cross-sectional regressions are reported in Tables $4 \mathrm{a}$ and $4 \mathrm{~b}$.

\section{Debt and capital flight}

Our single strongest finding is that external borrowing is an important determinant of capital flight. In the pooled data analysis, the change in external debt invariably has a positive and statistically significant effect, regardless of which additional

determinants of capital flight are included in the regressions. $\frac{16}{6}$ This result is also robust in the cross-sectional specification. The estimated coefficients of the change in debt reported in Tables $3 \mathrm{a}$ and $3 \mathrm{~b}$ range from approximately 0.7 to 0.9 , with an average value of 0.8. Since both capital flight and change in debt are measured as percentages of GDP, this implies that, for every dollar of external borrowing by a SSA country in a given year, roughly 80 cents left the country as capital flight. In the cross-sectional regressions reported in Tables $4 \mathrm{a}$ and $4 \mathrm{~b}$, the estimated coefficients on the change in debt range from 0.35 to 0.9 , with an average value of 0.75 .

By including both the change in debt and the one-year lag of the debt stock (again as a percentage of GDP) simultaneously in the equation, we are able to assess the relative importance of debt-fueled and debt-driven capital flight. We find that the debt stock/GDP ratio has a positive and statistically significant coefficient (Table 3a). This result supports the hypothesis that debt overhang has an independent effect on capital flight: a one-dollar increase in the stock of debt adds an estimated 3.5 cents to annual 
capital flight in subsequent years. These results suggest that external borrowing and capital flight are linked by both debt-fueled and debt-driven capital flight. 7

Our results also indicate that past capital flight has a positive effect on current capital flight. The coefficients on lagged capital flight are consistently positive and statistically significant, a finding that suggests hysteresis, or a tendency for capital flight to persist over time. This may reflect a habit-formation effect, as private actors gain experience in capital flight operations. It may also reflect a contagion effect, as capital flight corrodes the legitimacy of capital controls, particularly if the flight capitalists include government authorities. At the same time, capital flight may contribute to the deterioration of the macroeconomic environment, in turn sparking further capital flight.

[INSERT TABLES 3a AND 3b HERE]

[INSERT TABLES 4a AND 4b HERE]

\section{Effects of the macroeconomic environment}

Our results indicate that the growth rate differential between the African country and its OECD trading partners is negatively related to capital flight: higher growth leads to less capital flight. In panel annual data regressions, the negative coefficient on the growth rate differential (lagged one year) is statistically significant at the 5\% level. In the cross-sectional regressions, the coefficient on the growth differential (measured over the period as a whole) is statistically insignificant in the full set of 30 countries, but it is negative and statistically significant at the $5 \%$ level in the SILIC sub-set. We obtain similar results (not reported here for reasons of space) when we use the African country's 
growth rate or the growth rate differential between the African country and the Unites States.

The effect of inflation on capital flight is positive but statistically insignificant in the regressions with pooled annual data as well as in cross-sectional regressions. ${ }^{6}$ Again we find similar results when instead of the country's inflation rate we use the inflation differential between the African country and the United States.

The regressions with pooled annual data reveal a positive and statistically significant effect of exports on capital flight. The cross-sectional regressions, however, yield a negative and statistically insignificant coefficient on the exports/GDP ratio. The results suggest that exports help to explain within-country variations in capital flight over time, but not inter-country variations.

\section{Effects of fiscal policy}

The results on the primary budget surplus are ambiguous: the primary budget surplus has a negative and statistically significant effect of on capital flight in crosssectional regressions (Table 4a), but the effect is positive and statistically significant in regressions with pooled annual data (Table 3a). Regressions with other fiscal policy indicators - the overall deficit/GDP ratio and the tax/GDP ratio - produced statistically insignificant coefficients. As noted before, fiscal data for SSA are not well reported, as illustrated by the smaller number of observations in the regressions. Therefore, no firm 
conclusions can be drawn from our results on the links between capital flight and fiscal policy.

\section{Effects of risk and returns to investment}

The indicators of risk and returns to investment used in our analysis generally have little effect on capital flight. The estimated coefficient on the difference between domestic and U.S. interest rates (adjusted for exchange rate movements) has the expected negative sign in both the pooled and cross-sectional regressions, but in neither case is it statistically significant at the $10 \%$ level. In other regressions (not reported in the tables for reasons of space), we tested for the impacts of the change in the real exchange rate, the domestic deposit interest rate, and the spread between the domestic deposit and lending rates. The estimated coefficients had the expected negative sign only in the case of the change in the real exchange rate, and in no case were they statistically significant. These results suggest that conventional portfolio choice considerations, as measured by the differential returns to investment and exchange rate risk, have not been important determinants of capital flight from sub-Saharan Africa.

\section{Financial development}

We find that credit to the private sector has a negative and statistically significant effect on capital flight in cross-sectional regressions, and that this effect is nearly significant in panel data regressions (with a p-value of 0.11 ). This finding is consistent with the theory that suggests that financial deepening can reduce capital flight by increasing opportunities for domestic portfolio diversification. Our regression results 
indicate no significant relationship, however, between liquid liabilities and capital flight. The links between financial development and capital flight thus appear to be sensitive to the choice of the measure of financial intermediation.

\section{Political and governance indicators}

Our indicators of the political environment and the quality of governance are defined such that a higher value indicates a better environment in the cases of political freedom, voice and accountability, and government effectiveness; higher values for the risk of contract repudiation and corruption variables, on the other hand, indicate a worse environment. In the pooled data analysis, the estimated coefficients on all five variables have the expected signs but they are statistically significant only in the cases of voice and accountability and corruption. In the cross-sectional regressions, the coefficient on government effectiveness again has the expected sign and is close to being statistically significant with a p-value of 0.11 , while the coefficients on the other indicators are statistically insignificant. The weak explanatory power of the indicators of the political environment and governance is possibly due to the relatively small variation in their values both over time and across the countries in our study. 19

\section{POLICY IMPLICATIONS}

The foregoing analysis has implications both for "debt relief" policies and for policies to reduce future capital flight in sub-Saharan Africa. 


\section{(a) Implications for debt relief}

In recent years, the debilitating effects of high external debt burdens on developing countries have prompted widespread support for debt cancellation. The highly indebted poor countries (HIPC) debt relief initiative is an important step in this direction, but much remains to be done to pull African economies out of the high-debt, high-poverty trap.

The empirical evidence presented in this paper suggests an additional rationale for the annulment of debts. Private capital flight from SSA countries constitutes a large fraction of the total debt owed by these countries (Boyce and Ndikumana 2001). Furthermore, the results presented here indicate that to a large extent this capital flight was financed by foreign borrowing, a phenomenon we term debt-fueled capital flight. This implies that creditors knowingly or unknowingly financed the export of private capital rather than investment (or, for that matter, consumption) in African economies. Such lending was often motivated by political and strategic considerations. In the Congo (former Zaïre), for example, creditors continued to lend to the regime of the late president Mobutu despite ample knowledge that much of the borrowed funds were in fact being diverted into private assets (Ndikumana and Boyce 1998). In such circumstances, the ordinary people of sub-Saharan Africa may rightly ask why they, rather than the holders of the private assets that are the counterparts of public liabilities, should bear the responsibility for servicing the resulting debts. 
The phenomenon of debt-fueled capital flight implies a lack of diligence - if not active complicity - on the part of creditors. Well-functioning credit markets require that creditors face the consequences of irresponsible or politically motivated lending. A strategy of selective disengagement by successor governments from "odious debts" contracted by predecessor regimes therefore would be consistent with economic logic, as well as building upon precedents in international law (Boyce 1993, 2002). In this strategy, successor governments would accept liability for those portions of the public debt that were used to finance bona fide investment or public consumption, while repudiating liability for those portions for which no such use can be demonstrated. From the standpoint of successor governments, a potential drawback of the selective disengagement strategy is the danger that creditors will retaliate by withdrawing or rationing subsequent lending. Against this potential cost, however, the government must weigh the potential savings via reduced debt service payments. In SSA countries, where the net transfer (new borrowing minus debt service payments) has often been negative in the past decade, ${ }^{0}$ these immediate benefits may well outweigh the costs. Moreover, in the long run, if lenders do apply stricter criteria with respect to the uses to which their loans are put, so as to protect themselves from the threat of selective disengagement in future years, this arguably would be a desirable change from the standpoint of most citizens in the borrower countries.

In addition to greater accountability on the creditor side, it is equally important that debtor countries establish mechanisms of transparency and accountability in their own decision-making processes with regard to foreign borrowing and the management of 
borrowed funds. Since, in the absence of debt cancellation or selective disengagement, the burden of debt repayment ultimately lies with the population of the debtor countries, it is appropriate to require debtor governments to provide information to the public - just as they report to their creditors - and to ensure public representation in the management of public debt. In the future, greater accountability on the part of both borrowers and creditors will be needed to prevent new cycles of external borrowing, capital flight, and financial distress.

\section{(b) Capital flight: policy responses}

The hemorrhage of capital from sub-Saharan Africa points to the need for policies designed to stem further capital outflows and encourage the repatriation of legitimate private capital now held abroad.

\section{Prevention}

The evidence in this study and in several prior studies suggests that once capital flight begins, it tends to persist. The best way to stop capital flight therefore is to prevent it in the first place. At the same time, the evidence that much of the capital flight from SSA countries is debt-fueled suggests that efforts to promote more responsible lending on the part of creditors, and more accountable borrowing and debt management on the part of debtor governments, could help to rein in capital flight once it has begun.

Our results also suggest that capital flight can be reduced by strategies to promote growth, deepen financial markets, improve governance, and reduce debt overhang. These 
"push" factors generally appear to be more significant as predictors of capital flight than measures of relative risks and returns suggested by conventional portfolio theory. Steps to level the legal and administrative playing field for domestic investors and to promote a stable macroeconomic environment could contribute to these goals. African countries not only need to curb the de facto privatization of public assets (that leaves the corresponding liabilities in public hands), but also must endeavor to keep legitimate private capital at home by encouraging domestic investment.

Capital controls, another potential policy tool to reduce capital flight, have been out of fashion in recent years, but deserve consideration as one element of a broader policy mix. Some critics have argued that capital controls amount to "attacking the symptom rather than the underlying causes of the capital flight problem" (Cuddington 1986: 33). Others have argued that capital controls are either pernicious, preventing countries from reaping the benefits of free international financial markets (Khan and Haque 1985; Fischer 1999), or ineffectual since private actors find ways of circumventing them (Edwards 1999). As Bhagwati (1998) points out, however, proponents of free capital mobility fail to provide convincing evidence of the expected gains, while ignoring or downplaying the losses from financial crises associated with unregulated capital movements. Blinder (1999: 57) warns that "the hard-core Washington consensus - which holds that international capital mobility is a blessing, full stop - needs to be tempered by a little common sense." In sub-Saharan Africa, common sense may indicate that most countries do not meet the necessary conditions for benefiting from full capital account openness, including low barriers to international 
trade, a well-developed, well-diversified, and well-regulated financial system, and no

large differences with other countries' tax regimes on capital (see Cooper 1999). ${ }^{21}$ There is some empirical evidence that developing countries that maintained capital controls in the past experienced relatively lower capital flight (Pastor 1990). Capital controls cannot substitute for accountability and sound macroeconomic management, but they may be useful in dampening the effects of shortcomings on these fronts, shortcomings that will be inevitable even in the best of transitions from "here" to "there."

\section{Repatriation}

A number of policies have been proposed to entice private holders of external assets to repatriate their capital. Two of the most important are tax amnesties and raising domestic real interest rates. Tax amnesties involve the write-off of past tax liabilities on assets that were sent abroad, as well as tax exemptions for future earnings on repatriated private capital. One problem with this strategy is that private capital held abroad is not homogeneous. The pool includes capital acquired legally at home and transferred legally abroad, capital acquired legally at home but transferred abroad by illicit means, and private capital acquired illegally at home and funneled abroad illegally. Granting tax breaks to the latter types of capital not only rewards illicit activities, but also undermines the credibility of government policies (Dornbusch 1987).

The use of domestic real interest rates to induce capital repatriation also has serious limitations. Our results indicate that relative returns to capital have not been an important determinant of capital flight from sub-Saharan Africa. This implies that efforts 
to lure capital back by raising domestic interest rates are not likely to be terribly successful. At the same time, the adverse macroeconomic and sectoral effects of high interest rates may outweigh any potential gains from capital flight repatriation, as higher borrowing costs suffocate the already weak private sector in SSA countries.

\section{CONCLUSION}

This paper has explored the causes of capital flight in sub-Saharan Africa, a region that is still struggling with the debilitating effects of the debt crisis. Our findings indicate that external borrowing is the single most important determinant of capital flight. In the 1970-1996 period, roughly 80 cents on every dollar that flowed into the region from foreign loans flowed back out as capital flight in the same year, suggesting that the phenomenon of debt-fueled capital flight was widespread. In addition, every dollar added to the stock of external debt added roughly three cents to the annual capital flight in subsequent years, suggesting that outflows were exacerbated by the phenomenon of debtdriven capital flight. These findings imply that debt relief strategies will bring long-term benefits to African countries only if accompanied by measures to prevent a new cycle of external borrowing and capital flight. This will require substantial reforms on the part of both creditors and debtors to promote responsible lending and accountable debt management.

Our results also indicate that past capital flight tends to persist over time, and provide fairly robust support for the propositions that capital flight is negatively related to 
the growth rate differential between the African country and its OECD trade partners, the volume of domestic credit to the private sector, and a political-governance index of voice and accountability. These findings suggest that capital flight from sub-Saharan Africa can be reduced by improvements in these broader dimensions of economic performance and institutional reform, as well as by greater transparency and accountability in capital account transactions.

\section{NOTES}

${ }^{1}$ Conceptually, some authors have attempted to distinguish "capital flight" from "normal capital outflows" on the basis of its motivations or consequences (for discussion, see Lessard and Williamson 1987: 201-4). When it comes to practical measurement, however, it is difficult to do so. Like most authors, we therefore use the term "capital flight" to refer to all resident capital outflows from SSA, excluding recorded investment abroad.
}

\footnotetext{
${ }^{2}$ We eliminate Tanzania from the Boyce and Ndikumana (2001) sample due to lack of adequate data on other variables. We include revisions to the capital flight series for the Democratic Republic of Congo for the period 1990-1996 based on data from the World Development Indicators 2000.

${ }^{3}$ The World Bank classifies a country as severely indebted if "either the present value of debt service to GNP exceeds 80 percent or the present value of debt service to exports exceeds 220 percent" (World Development Indicators 2000). In 1996 a country was
} 
classified as low-income if its per capita GNP was less than or equal to $\$ 785$ (World Development Indicators 1998).

${ }^{4}$ Collier and Hoeffler (2001) report that the ratio of primary commodity exports to GDP is a strong predictor of the risk of civil conflict, a result they attribute to the potential for warring parties to capture "lootable" resources.

${ }^{5}$ Hermes and Lensink (2000) measure uncertainty of government tax policy by the unpredictable component of the tax/GDP ratio obtained as a residual from a forecasting equation specified as a second-order autoregressive process including a time trend.

${ }^{6}$ Theoretically, the overvaluation of a currency is determined in relation to some equilibrium exchange rate. In practice, a proxy typically is obtained by choosing a given year or period in which it is believed that a country had the appropriate (marketdetermined) exchange rate. Departure from this benchmark exchange rate is then interpreted as exchange rate misalignment (overvaluation or undervaluation). Cuddington (1986) and Pastor (1990) choose 1977 as the equilibrium year for Latin American countries. Murinde, Hermes, and Lensink (1996) and Hermes and Lensink (1992) choose the year 1984 for sub-Saharan African countries. Lensink, Hermes, and Murinde (1998) use the annual percentage change in the real effective exchange rate. Given the difficulty of choosing an 'equilibrium' year, we adopt the latter strategy in the following analysis. 
${ }^{7}$ Other commonly used measures of financial development include the M3/GDP ratio and various measures of the banking sector and stock market activity. For discussions of these measures, see Beck, Levine, and Loayza (2000), Levine (1997), and Lynch (1996).

${ }^{8}$ On trade misinvoicing, also see Bhagwati (1964) and Gulati (1987). See Boyce and Ndikumana (2001) for details on data sources and the algorithms used to adjust debt flows for cross-currency exchange rate fluctuations and for the computation of net trade misinvoicing.

${ }^{9}$ The reasons for these anomalous findings for these five countries, all in francophone West Africa, warrant further investigation.

${ }^{10}$ These indicators - like other measures of the quality of governance and the political environment - are open to criticism on both conceptual and data-quality grounds. Yet the fact that something is difficult to measure does not imply that it is unimportant. For this reason, we examine a variety of indicators.

${ }^{11}$ In the original sources, the indexes of risk of contract repudiation and corruption are reported on a scale of 0 to 10 such that a high number corresponds to low risk and low corruption. We transform the indexes (by subtracting the original value from 10) so that a high value indicates higher risk and higher corruption. 
${ }^{12}$ The unpredictable component is obtained as the residual from the following forecasting equation (estimated by country): $X_{t}=\gamma_{0}+\gamma_{1} X_{t-1}+\gamma_{2} t+\varepsilon_{t}$, where $X$ is the index of political freedom, risk of contract repudiation, or corruption, $t$ is time, and $\varepsilon$ is a stochastic error term. A similar approach is used by Hermes and Lensink (2000) to examine the effects of political and governance indicators.

${ }^{13}$ Since this is a dynamic model including lags of the dependent variable, random-effects estimation is not appropriate (correlation between the unobserved component and the lags of capital flight violates the orthogonality condition for consistency of random-effects estimates). For this reason we use the fixed-effects estimation method. For further discussions of the estimation of fixed-effects models with panel data, see Wooldridge (2002); Hsiao (1986); and Andersen and Hsiao (1981, 1982). F-tests indicate that country-specific effects are significant. In the benchmark model, for example, the $F$ statistic is 4.0 (with a critical value of 1.86 at the $1 \%$ level).

${ }^{14}$ In the cross-section regressions, a country's growth rate is obtained from an OLS regression of the logarithm of real per capita GDP on time over the relevant period.

${ }^{15}$ If the change in debt is endogenous, the ordinary least squares estimate $\hat{\phi}_{1, \mathrm{OLS}}$ will be inconsistent and will differ statistically from the instrumental-variable estimate $\hat{\phi}_{1, i v}$. We compute the Hausman specification test statistic $m$ as follows: $m=\left(\hat{\phi}_{1, i v}-\hat{\phi}_{1, \mathrm{OLS}}\right)^{2} /\left[\left(\operatorname{var}\left(\hat{\phi}_{1, i v}\right)-\operatorname{var}\left(\hat{\phi}_{1, \mathrm{OLS}}\right)\right] ;\right.$ it is distributed as $\chi^{2}{ }_{(1)}$. The $m$ 
statistic for our sample is 0.03 (the critical value is 6.6 at the $1 \%$ level and 2.7 at the $10 \%$ level). For discussion of the Hausman test, see also Griffiths, Hill, and Judge (1993).

${ }^{16}$ The result also holds if we limit the sample to the SILIC subset or if we drop Nigeria from the sample as an outlier (not reported here for reasons of space).

${ }^{17}$ The cross-sectional results in Table 4 do not permit us to differentiate between the two linkages, since the average change in debt is roughly proportional to the average debt stock.

${ }^{18}$ To permit non-linearity in the impact of inflation, we include a quadratic term.

${ }^{19}$ For example, on a 0 -to- 12 scale of the political freedom index, 23 of the 30 countries score a mean value between 1 and 3 (see Table A3).

${ }^{20}$ The net transfer on debt in the period 1990-98 was negative for the 30-country group taken as a whole, amounting to -0.5 percent of GNP. The largest negative net transfers were recorded by the Republic of Congo (-6.7\% of GNP) and Nigeria (-5.95\% of GNP). Excluding Nigeria, the net transfer for the other 29 countries amounted to $0.8 \%$ of GNP in this period.

${ }^{21}$ See Edwards (1999) for a review of the literature on capital control effectiveness. See also Kaplan and Rodrik (2001). 


\section{REFERENCES}

Ajayi, I. S. (1997). "An Analysis of External Debt and Capital Flight in the Severely Indebted Low Income Countries in Sub-Saharan Africa," IMF, Working Paper WP/97/68.

Alesina, A. and G. Tabellini (1989). "External Debt, Capital Flight and Political Risk," Journal of International Economics, 27, 199-220.

Anderson, T. W. and C. Hsiao (1981). "Estimation of dynamic models with error components," Journal of the American Statistical Association, 76(375), 598-606.

Anderson, T. W. and C. Hsiao (1982). "Formulation and estimation of dynamic models using panel data," Journal of Econometrics, 18, 83-114.

Annan, K. (2000). "Africa - Maintaining the Momentum," Commonwealth Lecture, London, 14 March. Available on the worldwide web at http://www.un.org/News/ossg/common.htm

Anthony, M. and A. H. Hallett (1992). "How Successfully Do We Measure Capital Flight? The Empirical Evidence from Five Developing Countries," Journal of Development Studies, 28(3), 538-556.

Beck, T., R. Levine, and N. Loayza (2000). "Finance and the sources of growth," Journal of Financial Economics, 58, 261-3000.

Bhagwati, J. N. (1964). "On the Underinvoicing of Imports," Bulletin of the Oxford University Institute of Statistics, November.

Bhagwati, J. N. (1998). "The Capital Myth: The Difference Between Trade in Widgets and Trade in Dollars." Foreign Affairs, 77, 7-12.

Blinder, A. S. (1999). "Eight Steps to a New Financial Order," Foreign Affairs, (September/October 1999), 50-63.

Boyce, J. K. (1992). "The Revolving Door? External Debt and Capital Flight: A Philippine Case Study," World Development, 20(3), 335-349.

Boyce, J. K. (1993). The Philippines: The Political Economy of Growth and Impoverishment in the Marcos Era. London: Macmillan Press.

Boyce, J. K. (2002). “Unpacking Aid,” Development and Change, 33 (2), 239-246.

Boyce, J. K. and L. Ndikumana (2001). "Is Africa a Net Creditor? New Estimates of Capital Flight from Severely Indebted Sub-Saharan African Countries, 1970-1996," Journal of Development Studies, 38(2), 27-56.

Collier, P., A. Hoeffler, and C. Pattillo (2001). "Flight Capital as a Portfolio Choice," World Bank Economic Review, 15(1), 55-80.

Collier, P. and A. Hoeffler (2001). "Greed and Grievance in Civil War," working paper, World Bank research program on the Economics of Crime and Violence, 4 January.

Cooper, R. (1999). "Should capital controls be banished?" Brookings Papers on Economic Activity 1, 89-141.

Cuddington, J. (1986). Capital Flight: Estimates, Issues, and Explanations. Princeton Studies in International Finance, no. 58. Princeton University, Department of Economics.

Cuddington, J. (1987). "Macroeconomic Determinants of Capital Flight: An Econometric Investigation," in Lessard, Donald and John Cuddington (Eds.) Capital Flight and Third World Debt. Washington, DC: Institute for International Economics, 85-96.

Dooley, M. (1988). "Capital Flight: A Response to Differences in Financial Risks," IMF Staff Papers, 35(3), 422-436. 
Dornbusch, R. (1987). "Comment” (on Miguel Rodriguez's 'Consequences of Capital Flight for Latin American Debtor Countries,'), in Lessard, Donald and John Cuddington (Eds.) Capital Flight and Third World Debt. Washington, DC: Institute for International Economics, 145-151.

Easterly, W. and H. Yu (2000). Global Development Network Growth Database. The World Bank.

Edwards, S. (1999). "How Effective Are Capital Controls?” Journal of Economic Perspectives, 13(4), 65-84.

Fischer, S. (1993). "The Role of Macroeconomic Factors in Growth," Journal of Monetary Economics, 32, 485-512.

Fischer, S. (1999). "Capital-account liberalization and the role of the IMF," in Should the IMF Pursue Capital-Account Convertibility? Princeton: Princeton University, Department of Economics, Essays in International Finance no. 207, 1-10.

Freedom House (2001). Freedom in the World: Country Ratings 1972-73 to 2000-01. New York.

Griffiths, W., C. Hill, and G. Judge (1993). Learning and Practicing Econometrics, New York: John Wiley and Sons, Inc.

Gulati, S. K. (1987). “A Note on Trade Misinvoicing,” in Lessard, Donald R. and John Williamson, eds., Capital Flight and Third World Debt. Washington, D.C.: Institute for International Economics, 68-78.

Hausman, J.A. (1978). "Specification Tests in Econometrics," Econometrica 46 (6), 1251-1271.

Henry, J. (1986). "Where the Money Went: Third World Debt Hoax," The New Republic, (April 14), 20-23.

Henry, L. (1996). "Capital Flight from Beautiful Places: The Case of Three Caribbean Countries," International Review of Applied Economics, 10(2), 263-272.

Hermes, N. and R. Lensink (1992). "The Magnitude and Determinants of Capital Flight: The Case for Six Sub-Saharan African Countries," De Economist, 140 (4), 515-530.

Hermes, N. and R. Lensink (2000). "Capital Flight and the Uncertainty of Government Policies," University of Groningen, unpublished manuscript.

Hsiao, C. (1986). Analysis of Panel Data, Cambridge University Press, New York.

Kaplan, E. and Rodrik, D. (2001). "Did the Malaysian Capital Controls Work?" Cambridge, MA: National Bureau of Economic Research, Working Paper 8142, February.

Kaufman, D., A. Kraay, and P. Zoido-Lobatón (1999). “Governance Matters," The World Bank, Policy Research Working Paper 2196.

Khan, M. and N. Ul Haque (1985). "Foreign Borrowing and Capital Flight," IMF Staff Papers, 32, 606-628.

Lensink, R., N. Hermes, and V. Murinde (1998). "The Effect of Financial Liberalization on Capital Flight in African Economies," World Development, 26(7), 1349-1368.

Lensink, R., N. Hermes, and V. Murinde (2000). "Capital Flight and Political Risk," Journal of International Money and Finance, 19, 73-92.

Lessard, D. R. and J. Williamson, eds. (1987). Capital Flight and Third World Debt. Washington, D.C.: Institute for International Economics.

Levine, R. (1997). "Financial Development and Economic Growth: Views and Agenda," Journal of Economic Literature, 35, 688-726.

Lynch, D. (1996). "Measuring financial sector development: A study of selected Asia-Pacific countries," Developing Economies, 32(1), 3-33. 
Mackenzie, G.A. (1989). “Are All Summary Indicators of the Stance of Fiscal Policy Misleading?” IMF Staff Papers 36, 743-770.

Mikkelsen, J. G. (1991). “An Econometric Investigation of Capital Flight," Applied Economics, 23, 73-85.

Murinde, V., N. Hermes, and R. Lensink (1996). "Comparative Aspects of the Magnitude and Determinants of Capital Flight in Six Sub-Saharan African Countries," Saving and Development, 20(1), 61-78.

Ndikumana, L. and J. K. Boyce (1998) “Congo's Odious Debt: External Borrowing and Capital Flight in Zaïre," Development and Change, 29, 1995-217.

Ng'eno, N.K. (2000) "Capital Flight in Kenya," in Ibi Ajayi and Mohsin Khan (Eds.) External Debt and Capital Flight in Sub-Saharan Africa. Washington, D.C.: The World Bank, 300-321.

Nyoni, T. (2000) "Capital Flight from Tanzania," in Ajayi, Ibi and Mohsin Khan (Eds.) External Debt and Capital Flight in Sub-Saharan Africa. Washington, D.C.: The IMF Institute, 265-299.

Olopoenia, R. (2000) "Capital Flight from Uganda, 1971-94," in Ajayi, Ibi and Mohsin Khan (Eds.) External Debt and Capital Flight in Sub-Saharan Africa. Washington, D.C.: The IMF Institute, 238-264.

Pastor, M. (1990) “Capital Flight From Latin America,” World Development, 18(1): 1-18. Political Risk Services (2000). International Country Risk Guide. East Syracuse, NY: The Political Risk Services Group, Inc.

Vos, R. (1992). "Private Foreign Asset Accumulation, Not Just Capital Flight: Evidence from the Philippines," Journal of Development Studies, 28(3), 500-537.

Wooldridge, J. (2002). Econometric Analysis of Cross Section and Panel Data. Cambridge: MIT Press.

World Bank (1985). World Development Report 1985. New York: Oxford University Press for the World Bank.

World Bank (1998). World Development Indicators 1998, CDROM edition.

World Bank (2000a). World Development Indicators 2000, CDROM edition.

World Bank (2000b). Global Development Finance 2000, CDROM edition.

World Bank (2000c). World Bank Africa Database 2000, CDROM edition.

World Bank (2000d). World Saving Database, available on line at: www.worldbank.org/research/projects/savings/data.htm 
Table 1: Selected Empirical Studies on Determinants of Capital Flight

\begin{tabular}{|c|c|c|c|c|c|c|c|}
\hline Authors & $\begin{array}{l}\text { Sample \& } \\
\text { method }\end{array}$ & Capital flows & $\begin{array}{l}\text { Macroeconomi } \\
\text { c environment }\end{array}$ & Fiscal policy & $\begin{array}{l}\text { Risk and } \\
\text { returns to } \\
\text { investments }\end{array}$ & Financial depth & $\begin{array}{l}\text { Political and } \\
\text { governance } \\
\text { factors }\end{array}$ \\
\hline \multicolumn{8}{|c|}{ A. Studies on Sub-Saharan Africa } \\
\hline $\begin{array}{l}\text { 1. Hermes } \\
\text { and Lensink } \\
\text { (1992) }\end{array}$ & $\begin{array}{l}6 \mathrm{SSA} \\
\text { countries, } \\
\text { 1976-1987: } \\
\text { pooled data } \\
\text { analysis }\end{array}$ & Debt flows (+) & $\begin{array}{l}\text { Growth }(0) ; \\
\text { inflation }(0)\end{array}$ & $\begin{array}{l}\text { Budget surplus } \\
(0) ; \operatorname{tax} / G D P(0)\end{array}$ & $\begin{array}{l}\text { Interest rate } \\
\text { differential }(0) \text {; } \\
\text { exchange rate } \\
\text { overvaluation } \\
(+)\end{array}$ & & \\
\hline $\begin{array}{l}\text { 2. Murinde, } \\
\text { Hermes, and } \\
\text { Lensink } \\
\text { (1996) }\end{array}$ & $\begin{array}{l}6 \text { SSA } \\
\text { countries, 1976- } \\
\text { 1991: time- } \\
\text { series analyses }\end{array}$ & $\begin{array}{l}\text { Debt flows } \\
(+/ 0) \text {; grants } \\
(+/-/ 0)\end{array}$ & $\begin{array}{l}\text { Growth }(+/ 0 /-) \text {; } \\
\text { inflation }(+/ 0)\end{array}$ & & $\begin{array}{l}\text { Interest rate } \\
\text { differential }(0) \text {; } \\
\text { exchange rate } \\
\text { overvaluation } \\
(+/ 0)\end{array}$ & & \\
\hline $\begin{array}{l}\text { 3. Lensink, } \\
\text { Hermes, and } \\
\text { Murinde } \\
\text { (1998) }\end{array}$ & $\begin{array}{l}9 \text { SSA } \\
\text { countries, } \\
\text { 1970-1991: } \\
\text { pooled data }\end{array}$ & Debt flows (+) & $\begin{array}{l}\text { Inflation }(+) ; \\
\text { lagged capital } \\
\text { stock }(-)\end{array}$ & & $\begin{array}{l}\text { Deposit rate }(-) ; \\
\text { expected change } \\
\text { in exchange rate } \\
(+)\end{array}$ & $\begin{array}{l}\text { Lagged demand } \\
\text { deposits (-) }\end{array}$ & \\
\hline $\begin{array}{l}\text { 4. Olopoenia } \\
(2000)\end{array}$ & $\begin{array}{l}\text { Uganda, 1971- } \\
1994\end{array}$ & & $\begin{array}{l}\text { Growth }(0) ; \\
\text { inflation }(+)\end{array}$ & & $\begin{array}{l}\text { Parallel market } \\
\text { premium }(0)\end{array}$ & & \\
\hline $\begin{array}{l}\text { 5. Nyoni } \\
(2000)\end{array}$ & $\begin{array}{l}\text { Tanzania, 1973- } \\
\text { 1992: } \\
\text { regressions in } \\
\text { first differences }\end{array}$ & $\begin{array}{l}\text { Debt flows }(0) \text {; } \\
\text { past capital } \\
\text { flight }(-)\end{array}$ & $\begin{array}{l}\text { Growth } \\
\text { differential }(+) \text {; } \\
\text { inflation }(0)\end{array}$ & & $\begin{array}{l}\text { Parallel market } \\
\text { premium }(0) ; \\
\text { interest rate } \\
\text { differential }(0)\end{array}$ & & $\begin{array}{l}\text { Political shock } \\
\text { dummy (0) }\end{array}$ \\
\hline
\end{tabular}


Table 1 (continued) Selected Empirical Studies on Determinants of Capital Flight

\begin{tabular}{|c|c|c|c|c|c|c|c|}
\hline Authors & Sample & Capital flows & $\begin{array}{l}\text { Macroeconomic } \\
\text { environment }\end{array}$ & Fiscal policy & $\begin{array}{l}\text { Risk and } \\
\text { returns to assets }\end{array}$ & Financial depth & $\begin{array}{l}\text { Political and } \\
\text { governance } \\
\text { factors }\end{array}$ \\
\hline $\begin{array}{l}\text { 6. Ng'eno } \\
(2000)\end{array}$ & $\begin{array}{l}\text { Kenya, quarterly } \\
\text { data 1981-1995 }\end{array}$ & & Real GDP (+) & & $\begin{array}{l}\text { Interest rate } \\
\text { differential (-); } \\
\text { exchange rate } \\
(+)\end{array}$ & & \\
\hline \multicolumn{8}{|c|}{ B. Studies on other countries (some samples including SSA countries) } \\
\hline $\begin{array}{l}7 . \\
\text { Cuddington } \\
(1987)\end{array}$ & $\begin{array}{l}7 \text { Latin } \\
\text { American } \\
\text { countries, 1974- } \\
\text { 1984: Time- } \\
\text { series analyses }\end{array}$ & $\begin{array}{l}\text { Debt flows } \\
(+/ 0) \text {; past } \\
\text { capital flight } \\
(+/ 0)\end{array}$ & Inflation $(+/ 0)$ & & $\begin{array}{l}\text { Real exchange } \\
\text { rate }(+) \text {; US } \\
\text { interest rate } \\
(+/ 0)\end{array}$ & & \\
\hline $\begin{array}{l}\text { 8. Dooley } \\
(1988)\end{array}$ & $\begin{array}{l}5 \text { Latin } \\
\text { American } \\
\text { countries + } \\
\text { Philippines, } \\
\text { 1976-1983: } \\
\text { pooled data }\end{array}$ & & Inflation $(+)$ & & $\begin{array}{l}\text { Financial } \\
\text { repression (+); } \\
\text { risk premium on } \\
\text { external debt (-) }\end{array}$ & & \\
\hline $\begin{array}{l}\text { 9. Pastor } \\
(1990)\end{array}$ & $\begin{array}{l}8 \text { Latin } \\
\text { American } \\
\text { countries, 1973- } \\
\text { 1986: pooled } \\
\text { data }\end{array}$ & Debt flows $(+)$ & $\begin{array}{l}\text { Growth } \\
\text { differential (-); } \\
\text { inflation (+/0) }\end{array}$ & $\begin{array}{l}\text { Change in } \\
\text { tax/GDP (0) }\end{array}$ & $\begin{array}{l}\text { Interest rate } \\
\text { differential }(+) \text {; } \\
\text { exchange rate } \\
\text { overvaluation } \\
(+)\end{array}$ & & \\
\hline
\end{tabular}


Table 1 (continued) Selected Empirical Studies on Determinants of Capital Flight

\begin{tabular}{|c|c|c|c|c|c|c|c|}
\hline Authors & Sample & Capital flows & $\begin{array}{l}\text { Macroeconomic } \\
\text { environment }\end{array}$ & Fiscal policy & $\begin{array}{l}\text { Risk and } \\
\text { returns to assets }\end{array}$ & Financial depth & $\begin{array}{l}\text { Political and } \\
\text { governance } \\
\text { factors }\end{array}$ \\
\hline $\begin{array}{l}10 . \\
\text { Mikkelsen } \\
(1991)\end{array}$ & $\begin{array}{l}22 \text { developing } \\
\text { countries, 1978- } \\
\text { 1985: pooled } \\
\text { data + time- } \\
\text { series analysis } \\
\text { for Mexico }\end{array}$ & $\begin{array}{l}\text { Debt flows (+); } \\
\text { past capital } \\
\text { flight }(+)\end{array}$ & Growth (-) & & $\begin{array}{l}\text { Expected } \\
\text { relative returns } \\
\text { on foreign vs. } \\
\text { domestic assets } \\
(+)\end{array}$ & & \\
\hline $\begin{array}{l}11 . \\
\text { Anthony } \\
\text { and Hollett } \\
(1992)\end{array}$ & $\begin{array}{l}4 \text { Latin } \\
\text { American } \\
\text { countries + } \\
\text { Philippines, } \\
\text { 1976-1988: } \\
\text { time-series } \\
\text { analysis }\end{array}$ & & Inflation $(+/ 0)$ & $\begin{array}{l}\text { Budget surplus } \\
(-/ 0)\end{array}$ & $\begin{array}{l}\text { Interest rate }(- \\
/ 0) ; \text { exchange } \\
\text { rate }(+/ 0) ; \\
\text { returns on } \\
\text { foreign assets } \\
(+/ 0)\end{array}$ & & \\
\hline $\begin{array}{l}\text { 12. Boyce } \\
(1992 ; \\
1993)\end{array}$ & $\begin{array}{l}\text { Philippines, } \\
\text { 1962-1986 }\end{array}$ & $\begin{array}{l}\text { Debt flows }(+) \text {; } \\
\text { past capital } \\
\text { flight }(0)\end{array}$ & Growth (0) & $\begin{array}{l}\text { Budget surplus } \\
(-)\end{array}$ & $\begin{array}{l}\text { Interest rate } \\
\text { differential }(+)\end{array}$ & & \\
\hline $\begin{array}{l}\text { 13. Vos } \\
(1992)\end{array}$ & $\begin{array}{l}\text { Philippines, } \\
\text { 1972-1988 }\end{array}$ & $\begin{array}{l}\text { Debt flows }(+) \text {; } \\
\text { debt stock }(0) \text {; } \\
\text { past capital } \\
\text { flight }(+)\end{array}$ & Inflation (0) & Tax/GDP (0) & $\begin{array}{l}\text { Interest rate } \\
\text { differential (+); } \\
\text { exchange rate } \\
\text { undervaluation } \\
(-)\end{array}$ & & \\
\hline
\end{tabular}


Table 1 (end) Selected Empirical Studies on Determinants of Capital Flight

\begin{tabular}{|c|c|c|c|c|c|c|c|}
\hline Authors & Sample & $\begin{array}{l}\text { Capital } \\
\text { flows }\end{array}$ & $\begin{array}{l}\text { Macroeconomic } \\
\text { environment }\end{array}$ & Fiscal policy & $\begin{array}{l}\text { Risk and } \\
\text { returns to assets }\end{array}$ & Financial depth & $\begin{array}{l}\text { Political and } \\
\text { governance } \\
\text { factors }\end{array}$ \\
\hline $\begin{array}{l}\text { 14. Henry } \\
\text { (1996) }\end{array}$ & $\begin{array}{l}\text { Barbados, Jamaica, } \\
\text { and Trinidad, 1971- } \\
\text { 1987: time-series } \\
\text { analyses }\end{array}$ & $\begin{array}{l}\text { Debt flows } \\
(+)\end{array}$ & $\begin{array}{l}\text { Growth }(-/ 0) \text {; } \\
\text { inflation }(-/ 0)\end{array}$ & $\begin{array}{l}\text { Budget surplus } \\
(-/ 0)\end{array}$ & $\begin{array}{l}\text { Interest rate } \\
\text { differential }(+) \text {; } \\
\text { exchange rate (- } \\
/ 0)\end{array}$ & & \\
\hline $\begin{array}{l}\text { 15. Hermes } \\
\text { and } \\
\text { Lensink } \\
(2000)\end{array}$ & $\begin{array}{l}84 \text { developing } \\
\text { countries, 1971- } \\
\text { 1991: cross-section } \\
\text { analysis }\end{array}$ & $\begin{array}{l}\text { Bank } \\
\text { lending } \\
(+/ 0) ; \\
\text { foreign aid } \\
(+)\end{array}$ & & $\begin{array}{l}\text { Policy } \\
\text { uncertainty: } \\
\text { government } \\
\text { consumption } \\
(+) \text {; tax }(+) ; \\
\text { deficit }(+) ; \\
\text { interest rate }(+) \text {; } \\
\text { inflation }(0)\end{array}$ & & & $\begin{array}{l}\text { Political } \\
\text { instability (+) }\end{array}$ \\
\hline $\begin{array}{l}16 . \\
\text { Lensink, } \\
\text { Hermes and } \\
\text { Murinde } \\
(2000)\end{array}$ & $\begin{array}{l}84 \text { developing } \\
\text { countries, 1971- } \\
\text { 1991: cross-section } \\
\text { analysis }\end{array}$ & $\begin{array}{l}\text { Bank and } \\
\text { trade-related } \\
\text { lending }(+) ; \\
\text { aid }(+) ; \text { FDI } \\
(0) ;\end{array}$ & & & & & $\begin{array}{l}\text { Political } \\
\text { instability (+); } \\
\text { democracy and } \\
\text { political } \\
\text { freedom (-); } \\
\text { war (+) }\end{array}$ \\
\hline $\begin{array}{l}\text { 17. Collier, } \\
\text { Hoeffler, } \\
\text { and Pattillo } \\
(2001)\end{array}$ & $\begin{array}{l}50 \text { countries } \\
\text { (including sub-set of } \\
22 \text { SSA countries); } \\
\text { 1980-1990; cross- } \\
\text { section analysis }\end{array}$ & $\begin{array}{l}\text { Debt stock } \\
\text { (squared) } \\
(+)\end{array}$ & $\begin{array}{l}\text { Capital stock } \\
(+/ 0)\end{array}$ & & $\begin{array}{l}\text { Dollar distortion } \\
\text { index (squared) } \\
(+) \text {; investor risk } \\
\text { (residuals) (0) }\end{array}$ & M2/GDP (0) & $\begin{array}{l}\text { Governance } \\
\text { indicators }(0)\end{array}$ \\
\hline
\end{tabular}

Notes: Symbols in parentheses denote a statistically significant positive effect $(+)$; no statistically significant effect $(0)$; or a statistically significant negative effect (-). Where more than one symbol appears in parentheses, this indicates that different specifications yielded different results or that the results vary by country. 
Table 2: Indicators of Capital Flight from 30 Sub-Saharan African Countries, 1970-1996 (million 1996 \$)

\begin{tabular}{|c|c|c|c|c|c|}
\hline \multirow[t]{2}{*}{ Country } & \multirow[t]{2}{*}{$\begin{array}{l}\text { Period } \\
\text { covered }\end{array}$} & $\begin{array}{r}\text { Real capital } \\
\text { flight }\end{array}$ & \multicolumn{2}{|c|}{$\begin{array}{r}\text { Cumulative stock of capital } \\
\text { flight } \\
\text { (including interest earnings) }\end{array}$} & \multirow[t]{2}{*}{ Net external assets } \\
\hline & & & Value (1996 m\$) & $\%$ of GDP & \\
\hline Angola & 1985-1996 & 17032.5 & 20405.0 & 267.8 & 9179.9 \\
\hline Benin & 1974-1996 & -3457.4 & -6003.8 & -271.9 & -7598.1 \\
\hline Burkina Faso & 1970-1994 & 1265.5 & 1896.6 & 96.5 & 700.4 \\
\hline Burundi & 1985-1996 & 818.9 & 980.9 & 108.9 & -146.0 \\
\hline Cameroon & $1970-1996$ & 13099.4 & 16906.0 & 185.6 & 7364.4 \\
\hline $\begin{array}{l}\text { Central African } \\
\text { Republic }\end{array}$ & 1970-1994 & 250.2 & 459.0 & 50.8 & -482.1 \\
\hline Congo, Dem. Rep. & 1970-1996 & 10035.4 & 19199.9 & 327.1 & 6373.5 \\
\hline Congo, Rep. & 1971-1996 & 459.2 & 1254.0 & 49.6 & -3986.6 \\
\hline Côte d'Ivoire & 1970-1996 & 23371.0 & 34745.5 & 324.7 & 15221.9 \\
\hline Ethiopia & 1970-1996 & 5522.8 & 8017.9 & 133.4 & -2060.7 \\
\hline Gabon & 1978-1996 & 2988.7 & 5028.1 & 87.0 & 717.7 \\
\hline Ghana & 1970-1996 & 407.3 & 289.3 & 4.2 & -6152.9 \\
\hline Guinea & 1986-1996 & 342.8 & 434.2 & 11.0 & -2806.1 \\
\hline Kenya & $1970-1996$ & 815.1 & 2472.6 & 26.8 & -4458.4 \\
\hline Madagascar & 1970-1996 & 1649.0 & 1577.5 & 39.5 & -2568.3 \\
\hline Malawi & 1970-1994 & 705.1 & 1174.8 & 93.8 & -971.3 \\
\hline Mali & $1970-1996$ & -1203.6 & -1527.2 & -57.5 & -4533.2 \\
\hline Mauritania & 1973-1995 & 1130.8 & 1830.0 & 167.4 & -572.2 \\
\hline Mauritius & 1975-1996 & -267.8 & 465.9 & 10.8 & -1351.7 \\
\hline Mozambique & $1982-1996$ & 5311.3 & 6206.9 & 218.4 & -1359.4 \\
\hline Niger & 1970-1995 & -3153.1 & -4768.9 & -247.7 & -6392.1 \\
\hline Nigeria & 1970-1996 & 86761.9 & 129661.0 & 367.3 & 98254.4 \\
\hline Rwanda & 1970-1996 & 2115.9 & 3513.9 & 249.9 & 2470.8 \\
\hline Senegal & 1974-1996 & -7278.1 & -9998.2 & -214.9 & -13661.1 \\
\hline Sierra Leone & 1970-1995 & 1472.8 & 2277.8 & 257.1 & 1072.7 \\
\hline Sudan & 1970-1996 & 6982.7 & 11613.7 & 161.1 & -5358.3 \\
\hline Togo & 1974-1994 & -1382.1 & -1618.3 & -155.4 & -3149.0 \\
\hline Uganda & 1970-1996 & 2154.9 & 3316.1 & 54.8 & -358.3 \\
\hline Zambia & $1970-1991$ & 10623.5 & 13131.2 & 354.9 & 5491.8 \\
\hline Zimbabwe & 1977-1994 & 8222.3 & 10882.9 & 149.0 & 6074.8 \\
\hline Total & & 186796.9 & 273824.3 & 171.9 & 84956.5 \\
\hline
\end{tabular}

Sources: For SILIC countries: Boyce and Ndikumana (2001). Series for non-SILIC countries are computed following the methodology in Boyce and Ndikumana (2001).

${ }^{\mathrm{a}}$ Net external assets = accumulated capital flight (with imputed interest earnings) minus stock of debt.. 
Table 3a: Determinants of Capital Flight: Fixed-Effects Regressions with Pooled Annual Data

\begin{tabular}{|c|c|c|c|c|c|c|}
\hline Explanatory variable & $\begin{array}{r}(1) \\
\text { Base model }\end{array}$ & $\begin{array}{r}(2) \\
\text { Expanded model }\end{array}$ & $\begin{array}{r}(3) \\
\text { Inflation }^{\mathrm{a}}\end{array}$ & $\begin{array}{r}(4) \\
\text { Exports }\end{array}$ & $\begin{array}{r}(5) \\
\text { Primary budget } \\
\text { surplus }\end{array}$ & $\begin{array}{r}\quad(6) \\
\text { Interest rate } \\
\text { differential }^{\mathrm{c}}\end{array}$ \\
\hline $1^{\text {st }}$ lag of capital flight $\left(K F_{-I}\right)$ & $\begin{array}{r}0.154 \\
(4.6)\end{array}$ & $\begin{array}{r}0.124 \\
(3.6)\end{array}$ & $\begin{array}{r}0.104 \\
(2.7)\end{array}$ & $\begin{array}{r}0.146 \\
(4.3)\end{array}$ & $\begin{array}{r}0.048 \\
(1.0)\end{array}$ & $\begin{array}{r}0.059 \\
(1.2)\end{array}$ \\
\hline $2^{\text {nd }}$ lag of capital flight $\left(K F_{-2}\right)$ & $\begin{array}{r}0.108 \\
(3.3)\end{array}$ & $\begin{array}{r}0.094 \\
(2.8)\end{array}$ & $\begin{array}{r}0.106 \\
(2.9)\end{array}$ & $\begin{array}{r}0.102 \\
(3.1)\end{array}$ & $\begin{array}{r}0.056 \\
(1.2)\end{array}$ & $\begin{array}{r}0.163 \\
(3.3)\end{array}$ \\
\hline Change in debt $(C D)$ & $\begin{array}{l}0.828 \\
(20.2)\end{array}$ & $\begin{array}{l}0.861 \\
(20.8)\end{array}$ & $\begin{array}{r}0.858 \\
(19.1)\end{array}$ & $\begin{array}{l}0.826 \\
(20.1)\end{array}$ & $\begin{array}{l}0.924 \\
(17.5)\end{array}$ & $\begin{array}{l}0.718 \\
(12.9)\end{array}$ \\
\hline Debt stock $\left(D E B T_{-1}\right)$ & & $\begin{array}{r}0.035 \\
(3.9)\end{array}$ & & & & \\
\hline Growth differential $\left(\right.$ DGROECD $\left._{-1}\right)$ & & $\begin{array}{r}-0.116 \\
(-2.3)\end{array}$ & & & & \\
\hline Inflation $\left(I N F L_{-1}\right)$ & & & $\begin{array}{r}0.001 \\
(0.1)\end{array}$ & & & \\
\hline Inflation squared $\left(I N F L_{-1}\right)^{2}$ & & & $\begin{array}{r}0.00008 \\
(0.6)\end{array}$ & & & \\
\hline Exports $\left(E X_{-1}\right)$ & & & & $\begin{array}{r}0.115 \\
(2.1)\end{array}$ & & \\
\hline Primary budget surplus $\left(P B S_{-1}\right)$ & & & & & $\begin{array}{r}0.167 \\
(1.7)\end{array}$ & \\
\hline Interest rate differential $\left(R D I F_{-1}\right)$ & & & & & & $\begin{array}{r}-0.018 \\
(-1.4)\end{array}$ \\
\hline Adjusted $R^{2}$ & 0.42 & 0.44 & 0.46 & 0.43 & 0.54 & 0.36 \\
\hline F-test (all coefficients $=0$ ) & 145.2 & 93.5 & 76.8 & 108.7 & 77.4 & 50.6 \\
\hline Number of observations & 586 & 577 & 440 & 578 & 257 & 348 \\
\hline
\end{tabular}

The dependent variable is the ratio of capital flight to GDP. The t-statistics are given in parenthesis.

${ }^{a}$ The regressions with inflation exclude the DRC and Angola (due to extremely high inflation rates), and Benin and Guinea (due to lack of data).

${ }^{\mathrm{b}}$ The regressions with the primary budget deficit exclude the DRC, Guinea, Kenya, Mauritania, Sudan, and Uganda (due to lack of data).

${ }^{c}$ The regressions with the interest rate differential (with exchange rate adjustment) exclude Angola, Benin, the DRC, Guinea, Madagascar, Mali, Mozambique, and Sudan (due to lack of data). 
Table 3b: Determinants of Capital Flight: Fixed-Effects Regressions with Pooled Annual Data

\begin{tabular}{|c|c|c|c|c|c|c|c|}
\hline Explanatory variable & $\begin{array}{r}(7) \\
\text { Liquid } \\
\text { liabilities }\end{array}$ & $\begin{array}{r}(8) \\
\text { Credit to } \\
\text { the private } \\
\text { sector }\end{array}$ & $\begin{array}{r}\text { (9) } \\
\text { Political } \\
\text { freedom }\end{array}$ & $\begin{array}{r}(10) \\
\text { Voice and } \\
\text { accountability }^{\mathrm{a}}\end{array}$ & $\begin{array}{r}\text { (11) } \\
\text { Government } \\
\text { effectiveness }^{\mathrm{a}}\end{array}$ & $\begin{array}{r}(12) \\
\text { Risk of } \\
\text { Contact } \\
\text { repudiation } \\
\end{array}$ & $\begin{array}{r}(13) \\
\text { Corruption }\end{array}$ \\
\hline Intercept & & & & $\begin{array}{r}-3.993 \\
(-7.8)\end{array}$ & $\begin{array}{r}-4.375 \\
(-7.5)\end{array}$ & & \\
\hline $\begin{array}{l}1^{\text {st }} \text { lag of capital flight } \\
\left(K F_{-I}\right)\end{array}$ & $\begin{array}{r}0.155 \\
(4.5)\end{array}$ & $\begin{array}{r}0.147 \\
(4.3)\end{array}$ & $\begin{array}{r}0.158 \\
(4.5)\end{array}$ & $\begin{array}{r}0.258 \\
(7.6)\end{array}$ & $\begin{array}{r}0.264 \\
(7.5)\end{array}$ & $\begin{array}{r}0.127 \\
(3.6)\end{array}$ & $\begin{array}{r}0.125 \\
(3.6)\end{array}$ \\
\hline $\begin{array}{l}2^{\text {nd }} \text { lag of capital flight } \\
\left(K F_{-2}\right)\end{array}$ & $\begin{array}{r}0.107 \\
(3.2)\end{array}$ & $\begin{array}{r}0.100 \\
(2.9)\end{array}$ & $\begin{array}{r}0.108 \\
(3.2)\end{array}$ & $\begin{array}{r}0.193 \\
(5.7)\end{array}$ & $\begin{array}{r}0.203 \\
(5.8)\end{array}$ & $\begin{array}{r}0.091 \\
(2.4)\end{array}$ & $\begin{array}{r}0.095 \\
(2.5)\end{array}$ \\
\hline Change in debt $(C D)$ & $\begin{array}{r}0.825 \\
(19.9)\end{array}$ & $\begin{array}{r}0.824 \\
(19.8)\end{array}$ & $\begin{array}{l}0.816 \\
(19.2)\end{array}$ & $\begin{array}{r}0.729 \\
(17.5)\end{array}$ & $\begin{array}{r}0.776 \\
(17.7)\end{array}$ & $\begin{array}{l}0.875 \\
(20.5)\end{array}$ & $\begin{array}{l}0.875 \\
(20.6)\end{array}$ \\
\hline $\begin{array}{l}\text { Liquid liabilities } \\
\qquad\left(M 3_{-1}\right)\end{array}$ & $\begin{array}{r}0.018 \\
(0.3)\end{array}$ & & & & & & \\
\hline $\begin{array}{l}\text { Credit to the private } \\
\text { sector }\left(C R E D_{-1}\right)\end{array}$ & & $\begin{array}{r}-0.110 \\
(-1.6)\end{array}$ & & & & & \\
\hline $\begin{array}{l}\text { Political freedom } \\
\qquad\left(F R E E_{-I}\right)\end{array}$ & & & $\begin{array}{r}-0.506 \\
(-1.5)\end{array}$ & & & & \\
\hline $\begin{array}{l}\text { Voice and accountability } \\
(\text { VOICE) }\end{array}$ & & & & $\begin{array}{r}-0.970 \\
(-1.8)\end{array}$ & & & \\
\hline $\begin{array}{l}\text { Government effectiveness } \\
(G O V E F F)\end{array}$ & & & & & $\begin{array}{r}-0.928 \\
(-1.4)\end{array}$ & & \\
\hline $\begin{array}{l}\text { Risk of contract } \\
\text { repudiation }\left(C O N T_{-I}\right)\end{array}$ & & & & & & $\begin{array}{r}1.615 \\
(1.4)\end{array}$ & \\
\hline Corruption $\left(C O R_{-1}\right)$ & & & & & & & $\begin{array}{r}2.581 \\
(1.7)\end{array}$ \\
\hline Adjusted $R^{2}$ & 0.42 & 0.43 & 0.42 & 0.44 & 0.47 & 0.49 & 0.49 \\
\hline F-test $($ all coeff. $=0$ ) & 106.7 & 105.8 & 101.3 & 118.3 & 119.4 & 110.3 & 111.1 \\
\hline Observations & 573 & 565 & 547 & 585 & 532 & 456 & 456 \\
\hline
\end{tabular}

The dependent variable is the ratio of capital flight to GDP. The t-statistics are given in parenthesis.

${ }^{a}$ For the regressions with indexes of voice and accountability and government effectiveness, the data are not mean-differenced because these two indexes are available as one observation per country. 
Table 4a: Determinants of Capital Flight: Cross-Section Regressions

\begin{tabular}{|c|c|c|c|c|c|c|c|c|}
\hline $\begin{array}{l}\text { Explanatory } \\
\text { variable }\end{array}$ & $\begin{array}{c}(1) \\
\text { Base } \\
\text { model }\end{array}$ & $\begin{array}{l}\quad(2) \\
\text { Growth } \\
\text { Differ- } \\
\text { ential }\end{array}$ & $\begin{array}{r}(3) \\
\text { Inflation }\end{array}$ & $\begin{array}{r}(4) \\
\text { Exports }\end{array}$ & $\begin{array}{r}\text { (5) } \\
\text { Primary } \\
\text { budget } \\
\text { surplus }\end{array}$ & $\begin{array}{r}\text { (6) } \\
\text { Interest rate } \\
\text { differential }\end{array}$ & $\begin{array}{r}(7) \\
\text { Liquid } \\
\text { liabilities }\end{array}$ & $\begin{array}{r}(8) \\
\text { Credit to } \\
\text { private } \\
\text { sector }\end{array}$ \\
\hline Intercept & $\begin{array}{r}-1.949 \\
(-0.9)\end{array}$ & $\begin{array}{r}-3.170 \\
(-1.4)\end{array}$ & $\begin{array}{l}-1.736 \\
\left(-0.8^{\prime}\right)\end{array}$ & $\begin{array}{r}-1.799 \\
(-0.7)\end{array}$ & $\begin{array}{r}-3.772 \\
(-1.8)\end{array}$ & $\begin{array}{r}0.030 \\
(0.01)\end{array}$ & $\begin{array}{r}-2.491 \\
(-0.9)\end{array}$ & $\begin{array}{r}0.143 \\
(0.1)\end{array}$ \\
\hline $\begin{array}{l}\text { Initial capital flight } \\
\left(K F_{0}\right)\end{array}$ & $\begin{array}{r}0.134 \\
(1.3)\end{array}$ & & & & & & & \\
\hline $\begin{array}{l}\text { Change in debt } \\
(C D)\end{array}$ & $\begin{array}{r}0.664 \\
(2.2)\end{array}$ & $\begin{array}{r}0.781 \\
(2.8)\end{array}$ & $\begin{array}{r}0.405 \\
(1.6)\end{array}$ & $\begin{array}{r}0.822 \\
(2.8)\end{array}$ & $\begin{array}{r}0.742 \\
(2.6)\end{array}$ & $\begin{array}{r}0.349 \\
(1.0)\end{array}$ & $\begin{array}{r}0.785 \\
(2.6)\end{array}$ & $\begin{array}{r}0.913 \\
(3.4)\end{array}$ \\
\hline $\begin{array}{l}\text { Growth differential } \\
(D G R O E C D)\end{array}$ & & $\begin{array}{r}-0.485 \\
(-0.8)\end{array}$ & & & & & & \\
\hline Inflation (INFL) & & & $\begin{array}{r}0.118 \\
(0.8)\end{array}$ & & & & & \\
\hline $\begin{array}{l}\text { Inflation squared } \\
\left(I N F L^{2}\right)\end{array}$ & & & $\begin{array}{r}-0.0005 \\
(-0.3)\end{array}$ & & & & & \\
\hline Exports $(E X)$ & & & & $\begin{array}{r}-0.023 \\
(-0.3)\end{array}$ & & & & \\
\hline $\begin{array}{l}\text { Primary budget } \\
\text { Surplus }(P B S)\end{array}$ & & & & & $\begin{array}{r}-0.724 \\
(-3.0)\end{array}$ & & & \\
\hline $\begin{array}{l}\text { Interest rate } \\
\text { differential }(R D I F)\end{array}$ & & & & & & $\begin{array}{l}-0.04 \\
(-0.8)\end{array}$ & & \\
\hline $\begin{array}{l}\text { Liquid liabilities } \\
(M 3)\end{array}$ & & & & & & & $\begin{array}{r}0.015 \\
(0.1)\end{array}$ & \\
\hline $\begin{array}{l}\text { Credit to private } \\
\text { sector }(C R E D)\end{array}$ & & & & & & & & $\begin{array}{r}-0.199 \\
(-1.9)\end{array}$ \\
\hline Adjusted $R^{2}$ & 0.22 & 0.19 & 0.19 & 0.17 & 0.42 & 0.08 & 0.17 & 0.28 \\
\hline$F$-test $($ all coeff. $=0)$ & 5.0 & 54.8 & 3.0 & 4.0 & 9.2 & 0.9 & 4.0 & 6.5 \\
\hline Observations $^{a}$ & 30 & 30 & 26 & 30 & 24 & 22 & 30 & 30 \\
\hline
\end{tabular}

The dependent variable is the country's average ratio of capital flight to GDP over the relevant period. The t statistics are given in parenthesis.

${ }^{\text {a }}$ For excluded countries in some regressions, see Table 3. 
Table 4b: Determinants of Capital Flight: Cross-Section Regressions

\begin{tabular}{|c|c|c|c|c|c|}
\hline Explanatory variable & $\begin{array}{r}\text { (9) } \\
\text { Political } \\
\text { freedom } \\
\end{array}$ & $\begin{array}{r}(10) \\
\text { Voice and } \\
\text { accountability }\end{array}$ & $\begin{array}{r}\text { (11) } \\
\text { Government } \\
\text { effectiveness }\end{array}$ & $\begin{array}{r}(12) \\
\text { Risk of Contact } \\
\text { repudiation }\end{array}$ & $\begin{array}{r}(13) \\
\text { Corruption }\end{array}$ \\
\hline Intercept & $\begin{array}{r}-1.721 \\
(-0.6)\end{array}$ & $\begin{array}{r}-3.427 \\
(-1.6)\end{array}$ & $\begin{array}{r}-5.129 \\
(-2.1)\end{array}$ & $\begin{array}{l}-0.159 \\
(-0.03)\end{array}$ & $\begin{array}{r}-6.310 \\
(-0.8)\end{array}$ \\
\hline Change in debt $(C D)$ & $\begin{array}{r}0.782 \\
(2.7)\end{array}$ & $\begin{array}{r}0.803 \\
(2.9)\end{array}$ & $\begin{array}{r}0.966 \\
(3.2)\end{array}$ & $\begin{array}{r}0.901 \\
(2.8)\end{array}$ & $\begin{array}{r}0.908 \\
(2.9)\end{array}$ \\
\hline Political freedom (FREE) & $\begin{array}{r}-0.134 \\
(-0.2)\end{array}$ & & & & \\
\hline Voice and accountability (VOICE) & & $\begin{array}{r}-2.121 \\
(-1.5)\end{array}$ & & & \\
\hline $\begin{array}{l}\text { Government effectiveness } \\
\quad(G O V E F F)\end{array}$ & & & $\begin{array}{r}-2.864 \\
(-1.6)\end{array}$ & & \\
\hline $\begin{array}{l}\text { Risk of contract repudiation } \\
\quad(C O N T)\end{array}$ & & & & $\begin{array}{r}-0.478 \\
(-0.4)\end{array}$ & \\
\hline Corruption $(C O R)$ & & & & & $\begin{array}{r}0.484 \\
(0.5)\end{array}$ \\
\hline Adjusted $R^{2}$ & 0.17 & 0.23 & 0.29 & 0.21 & 0.21 \\
\hline$F$-test $($ all coeff $=0)$ & 4.0 & 5.5 & 6.2 & 4.1 & 4.1 \\
\hline Observations & 30 & 30 & 27 & 24 & 24 \\
\hline
\end{tabular}

The dependent variable is the country's average ratio of capital flight to GDP over the relevant period. The t statistics are given in parenthesis. 
Table A1: Real Capital Flight (million 1996 US \$) for 30 SSA Countries

\begin{tabular}{|c|c|c|c|c|c|c|c|c|c|c|c|}
\hline Year & 1970 & 1971 & 1972 & 1973 & 1974 & 1975 & 1976 & 1977 & 1978 & 1979 & 1980 \\
\hline Angola & $\mathrm{NA}$ & $\mathrm{NA}$ & $\mathrm{NA}$ & $\mathrm{NA}$ & $\mathrm{NA}$ & NA & $\mathrm{NA}$ & NA & $\mathrm{NA}$ & $\mathrm{NA}$ & $\mathrm{NA}$ \\
\hline Benin & NA & NA & NA & NA & 70.1 & -5.6 & -157.2 & -85.4 & -144.5 & -167.3 & -599.1 \\
\hline Burkina Faso & 50.4 & 49.3 & 15.1 & 19.6 & 122.1 & -46.4 & -14.1 & 105.6 & 167.6 & 36.2 & 139.5 \\
\hline Burundi & NA & NA & NA & NA & NA & NA & NA & NA & NA & NA & NA \\
\hline Cameroon & -84.7 & -31.6 & -267.7 & -474.6 & -21.7 & 144.4 & -110.0 & 462.7 & 128.1 & -392.8 & 232.1 \\
\hline Central African Rep. & -15.3 & 17.4 & 21.4 & 76.2 & -4.5 & -7.2 & 31.5 & -25.7 & -25.0 & -11.1 & -10.1 \\
\hline Congo, Dem. Rep. & 801.6 & 263.8 & 849.9 & 1907.2 & 1534.9 & 99.8 & 465.3 & -1567.2 & 2002.9 & 771.9 & 916.1 \\
\hline Congo, Rep. & NA & -51.4 & -11.5 & 116.9 & -231.5 & -494.3 & -853.3 & -60.5 & 253.0 & 234.4 & 439.6 \\
\hline Côte d'Ivoire & 267 & 306.2 & 388.2 & 481.0 & 244.4 & 853.5 & 576.5 & 1969.2 & 1404.6 & 260.5 & 1323.6 \\
\hline Ethiopia & 31.9 & -10.2 & -530.7 & 78.8 & -97.5 & -76.7 & -217.5 & -113.2 & 17.6 & -106.9 & -168.1 \\
\hline Gabon & NA & NA & NA & NA & NA & NA & NA & NA & 450.5 & 675.0 & 397.4 \\
\hline Ghana & -53.3 & -294.1 & 317.8 & 370.4 & -610.4 & 133.3 & -370.2 & 114.4 & -37.3 & 110.4 & 304.3 \\
\hline Guinea & NA & NA & NA & NA & NA & NA & NA & NA & NA & NA & NA \\
\hline Kenya & 36.4 & 90.4 & 84.1 & 412.1 & 526.6 & 449.4 & 345.8 & 84.6 & 190.8 & -38.4 & 77.9 \\
\hline Madagascar & 22.6 & 1381.2 & 270.4 & -82.7 & 655.4 & 180.7 & -1327.7 & 1424.4 & -1170.0 & -85.1 & -300.1 \\
\hline Malawi & 11.1 & 88.5 & -35.4 & 161.9 & 143.2 & 192.9 & 161.1 & 156.7 & 52.7 & -352.1 & -63 \\
\hline Mali & 58.2 & -88.9 & 51.2 & 80.0 & 50.4 & -62.2 & -131.6 & -35.2 & -2.2 & -230.8 & 58.5 \\
\hline Mauritania & NA & NA & NA & 304.1 & 408.6 & -214.8 & 230.6 & 57.4 & 75.5 & -106.7 & 4.1 \\
\hline Mauritius & NA & NA & NA & NA & NA & NA & 140.2 & 92.9 & 100.2 & 71.3 & 136.8 \\
\hline Mozambique & NA & NA & NA & NA & NA & NA & NA & NA & NA & NA & NA \\
\hline Niger & 55.2 & 62.4 & 83.1 & 104.2 & -180.8 & -193.8 & -320.4 & -321.6 & 1.0 & -478.5 & 88.1 \\
\hline Nigeria & -485.1 & -564.2 & 626.1 & 3634.8 & 1448.2 & 1857.7 & 4162.4 & 9022.8 & 4060.4 & -612.9 & 2093.1 \\
\hline Rwanda & -106.1 & 30.7 & 24.7 & 34.4 & 34.9 & 67.7 & 77.0 & 119.0 & 288.7 & 320.9 & 223.8 \\
\hline Senegal & NA & NA & NA & NA & -329.9 & -67.5 & -222.6 & 63.8 & -102.1 & -506.0 & -135.9 \\
\hline Sierra Leone & 42.9 & 236.0 & 32.6 & 299.0 & 185.3 & -26.8 & 92.8 & 92.2 & 3.7 & 29.3 & 57.1 \\
\hline Sudan & 45.3 & 107.2 & -226.8 & 115.8 & 673.8 & 270.5 & 307.4 & 206.3 & -215.7 & 545.2 & 1004.1 \\
\hline Togo & NA & NA & NA & NA & 160.6 & -183.4 & 28.5 & 273.9 & 94.3 & 160.8 & -50.4 \\
\hline Uganda & 213.2 & 67.9 & 6.2 & 136.7 & 64.1 & -23.3 & 51.8 & -306.3 & -90.7 & 325.2 & 70.4 \\
\hline Zambia & 1386.4 & 1328.7 & 104.4 & 260.7 & -393.4 & 104.3 & 84.3 & 605.2 & 455.5 & 944.3 & -274.6 \\
\hline Zimbabwe & NA & NA & NA & NA & NA & NA & NA & 98.3 & 403.9 & -118.6 & 238.4 \\
\hline
\end{tabular}


Table A1 (continued): Real Capital Flight (million 1996 US \$) for 30 SSA Countries

\begin{tabular}{|c|c|c|c|c|c|c|c|c|c|c|}
\hline Year & 1981 & 1982 & 1983 & 1984 & 1985 & 1986 & 1987 & 1988 & 1989 & 1990 \\
\hline Angola & $\mathrm{NA}$ & NA & NA & $\mathrm{NA}$ & 2452.0 & 724.2 & 2803.8 & 533.4 & 1144.7 & 731.9 \\
\hline Benin & -532.3 & -771.6 & -96.9 & -98.6 & -174.3 & -60.4 & -60.7 & -102.1 & 254.7 & -212.4 \\
\hline Burkina Faso & 86.9 & 79.8 & 55.9 & 48.5 & -47.0 & 52.7 & 36.5 & -7.3 & 23.1 & 77.8 \\
\hline Burundi & NA & NA & NA & NA & 82.7 & 103.5 & 181.2 & 20.6 & 34.4 & -5.1 \\
\hline Cameroon & 222.6 & 329.6 & 629.2 & 1900.0 & -244.0 & 2166.4 & 1271.3 & 427.8 & 1371.0 & 1083.3 \\
\hline Central African Republic & 132.3 & 62.6 & 42.4 & 51.3 & 28.4 & 1.5 & 44.2 & 28.7 & -36.0 & -104.1 \\
\hline Congo, Dem. Rep. & 1715.9 & 530.0 & 289.2 & -79.8 & 778.2 & 366.4 & 514.7 & -585.6 & -292.2 & 183.8 \\
\hline Congo, Rep. & -240.5 & 623.2 & 392.2 & 690.4 & 688.5 & -326.8 & 886.8 & -390.2 & 215.6 & -177.8 \\
\hline Côte d'Ivoire & 289.6 & 969.5 & 183.3 & 212.7 & 701.0 & 1015.2 & 1718.5 & 1033.7 & 1375.9 & 2703.4 \\
\hline Ethiopia & 772.2 & 1649.2 & 618.8 & 185.6 & 707.6 & 421.3 & 1340.0 & -471.1 & -270.9 & 425.1 \\
\hline Gabon & 45.9 & 223.2 & 304.7 & -47.1 & 24.6 & -292.8 & 255.0 & -122.2 & 267.1 & 406.6 \\
\hline Ghana & -638.9 & 100.9 & 422.4 & 464.0 & -77.0 & -489.6 & 387.2 & -333.5 & 301.5 & 59.4 \\
\hline Guinea & NA & NA & NA & NA & NA & 120.1 & 217.9 & 48.4 & -328.0 & 171.9 \\
\hline Kenya & -331.4 & -123.7 & 241.3 & -431.3 & 625.0 & -259.4 & 567.4 & -310.3 & -333.8 & 316.7 \\
\hline Madagascar & -408.2 & -72.0 & -156.9 & 190.7 & -14.4 & 92.1 & 314.2 & -110.0 & -479.2 & -69.2 \\
\hline Malawi & -30.5 & -4.8 & 88.5 & -89.4 & 141.1 & 149.4 & 177.0 & 142.4 & 326.0 & 55.2 \\
\hline Mali & 70.4 & 30.0 & 83.7 & 201.3 & -145.6 & -282.6 & -121.5 & -310.3 & -169.7 & 65.9 \\
\hline Mauritania & -28.8 & 80.9 & 101.7 & 127.8 & 82.6 & -61.5 & 2.7 & -21.9 & -150.1 & 115.9 \\
\hline Mauritius & 331.2 & 109.8 & 5.4 & -3.1 & -13.4 & -36.4 & -228.4 & -165.4 & -215.5 & 27.4 \\
\hline Mozambique & NA & -398.3 & -110.9 & 830.1 & 1373.8 & 121.8 & 84.3 & -299.0 & -223.5 & 175.7 \\
\hline Niger & -185.0 & -364.7 & 29.4 & 49.0 & 15.0 & -92.3 & -209.9 & -131.5 & -533.5 & 44.2 \\
\hline Nigeria & 9293.6 & -509.4 & 2836.1 & 341.2 & 2443.8 & 5835.9 & 5762.2 & 2164.5 & 2314.7 & 5105.5 \\
\hline Rwanda & -24.4 & 42.4 & 32.4 & 77.0 & 89.5 & 131.5 & 153.9 & 153.9 & 15.3 & 133.5 \\
\hline Senegal & -183.1 & -278.0 & -135.3 & -126.6 & -436.0 & -161.4 & -52.2 & -549.0 & -1139.7 & -140.5 \\
\hline Sierra Leone & 72.3 & -158.8 & 78.6 & 31.6 & -34.0 & 56.2 & 91.7 & 21.8 & 20.2 & 13.6 \\
\hline Sudan & 303.7 & -182.8 & -97.0 & 1405.1 & 398.2 & -161.8 & 599.1 & 61.5 & 2192.5 & 845.8 \\
\hline Togo & -95.4 & -245.7 & -379.7 & -198.4 & -90.1 & -137.7 & -83.7 & -55.3 & 14.7 & -141.5 \\
\hline Uganda & 219.0 & 197.8 & 178.5 & 260.8 & 35.0 & 76.4 & 329.8 & -207.2 & -10.5 & 142.4 \\
\hline Zambia & 914.2 & -493.1 & 41.1 & 284.8 & 274.6 & 1099.4 & 830.1 & 825.9 & 1488.2 & 743.9 \\
\hline Zimbabwe & 891.9 & 977.8 & 528.1 & 383.0 & 150.6 & 487.6 & 991.2 & 187.4 & 718.0 & 314.7 \\
\hline
\end{tabular}


Table A1 (end): Real Capital Flight (million 1996 US \$) for 30 SSA Countries

\begin{tabular}{lrrrrrr}
\hline Year & 1991 & 1992 & 1993 & 1994 & 1995 & 1996 \\
\hline Angola & 2002.7 & 1820.7 & 1438.0 & 1526.2 & 1566.9 & 288.0 \\
Benin & -308.9 & -24.5 & -175.5 & 101.0 & 4.6 & -110.7 \\
Burkina Faso & -40.6 & 139.7 & 87.6 & 26.9 & $\mathrm{NA}$ & $\mathrm{NA}$ \\
Burundi & 23.8 & 63.9 & 86.9 & 49.7 & 203.5 & -26.4 \\
Cameroon & 815.1 & 1545.1 & 426.8 & 820.6 & 421.4 & 329.2 \\
Central African Republic & 70.5 & -89.0 & -24.9 & -5.2 & $\mathrm{NA}$ & $\mathrm{NA}$ \\
Congo, Dem. Rep. & -513.6 & -646.7 & -166.7 & 241.7 & 270.2 & -616.9 \\
Congo, Rep. & -82.3 & 353.2 & 38.9 & -372.7 & 255.4 & -1435.9 \\
Côte d'Ivoire & 1758.9 & 1314.3 & 1570.5 & -1574.5 & 1429.4 & 594.8 \\
Ethiopia & 380.8 & 395.8 & 263.4 & 452.5 & 71.5 & -226.3 \\
Gabon & 160.0 & -127.7 & -97.0 & 146.5 & 54.7 & 264.5 \\
Ghana & -358.3 & 144.9 & -224.2 & 196.3 & 84.5 & 382.5 \\
Guinea & 21.0 & -55.7 & 243.9 & 64.3 & -73.6 & -87.4 \\
Kenya & -6.8 & -263.7 & -194.1 & -205.3 & -15.9 & -719.3 \\
Madagascar & 416.8 & 298.3 & 103.6 & 286.1 & 451.0 & -163.1 \\
Malawi & -181.8 & -180.6 & -109.5 & -295.6 & $\mathrm{NA}$ & $\mathrm{NA}$ \\
Mali & -83.4 & 255.6 & -51.3 & -429.3 & 68.6 & -132.8 \\
Mauritania & 14.4 & -249.5 & 169.5 & 61.6 & 126.4 & $\mathrm{NA}$ \\
Mauritius & -76.8 & -41.6 & -178.2 & -158.5 & -7.0 & -158.7 \\
Mozambique & 191.5 & 709.9 & 336.2 & 2201.4 & 63.0 & 255.4 \\
Niger & -370.3 & 57.2 & -70.0 & -170.6 & -118.9 & $\mathrm{NA}$ \\
Nigeria & 8387.7 & 5688.6 & 4066.9 & 2851.8 & 1475.5 & 3459.9 \\
Rwanda & 103.6 & 2.7 & -29.9 & -37.6 & 81.6 & 74.6 \\
Senegal & -662.6 & -530.6 & -599.4 & -431.5 & -49.6 & -502.4 \\
Sierra Leone & 215.6 & 310.0 & 102.6 & 31.8 & -424.5 & $\mathrm{NA}$ \\
Sudan & -199.8 & 122.6 & 154.6 & 82.6 & -198.6 & -1176.1 \\
Togo & -306.9 & -48.0 & -154.0 & 55.4 & $\mathrm{NA}$ & $\mathrm{NA}$ \\
Uganda & 41.0 & 70.5 & 54.0 & 250.8 & 24.9 & -23.3 \\
Zambia & 8.6 & $\mathrm{NA}$ & $\mathrm{NA}$ & $\mathrm{NA}$ & $\mathrm{NA}$ & $\mathrm{NA}$ \\
Zimbabwe & 459.8 & 1103.4 & 478.4 & -71.0 & $\mathrm{NA}$ & $\mathrm{NA}$ \\
\hline Sourcs: Boyci
\end{tabular}

Sources: Boyce and Ndikumana (2001) for SILIC countries; series for non-SILIC countries are computed using the methodology in Boyce and Ndikumana (2001). 
Table A2: Variables: Definitions and Sources

\begin{tabular}{|c|c|c|}
\hline Variable & Definition & Source \\
\hline \multicolumn{3}{|c|}{ Dependent variable } \\
\hline$K F$ & Ratio of capital flight to GDP & $\begin{array}{l}\text { Table A1 and World } \\
\text { Bank (200a) }\end{array}$ \\
\hline \multicolumn{3}{|c|}{ Independent variables } \\
\hline \multicolumn{3}{|c|}{ I. Capital flows } \\
\hline$C D$ & $\begin{array}{l}\text { Change in debt (adjusted for exchange rate fluctuations) as } \\
\% \text { of GDP, annual series }\end{array}$ & World Bank (2000b) \\
\hline$D E B T$ & Total debt stock as $\%$ of GDP & $\begin{array}{l}\text { World Bank } \\
\text { (2000b), World } \\
\text { Bank (2000a) }\end{array}$ \\
\hline \multicolumn{3}{|c|}{ II. Macroeconomic environment } \\
\hline$G R$ & Annual growth rate of real per capita GDP & World Bank (2000a) \\
\hline DGRUS & Growth differential (domestic minus USA) & World Bank (2000a) \\
\hline$D G R O E C D$ & $\begin{array}{l}\text { Growth differential (domestic minus OECD trading } \\
\text { partners) }\end{array}$ & $\begin{array}{l}\text { Easterly and } \mathrm{Yu} \\
(2000)\end{array}$ \\
\hline INFL & Inflation rate $=$ growth rate of the CPI index & World Bank (2000a) \\
\hline DINFL & Inflation differential (domestic minus USA) & World Bank (2000a) \\
\hline$E X$ & Exports/GDP ratio & World Bank (2000a) \\
\hline
\end{tabular}

\section{Fiscal policy}

$B S \quad$ Overall budget surplus (deficit) as \% of GDP World Bank (2000a)

$P B S \quad$ Primary budget surplus (deficit) as \% of GDP

World Bank (2000c)

TAX Tax revenue as \% of GDP

World Bank (2000a)

\section{Risk and returns to investment}

\begin{tabular}{|c|c|c|}
\hline CREER & $\begin{array}{l}\text { \% change in real effective exchange rate REER (index } \\
\text { 1995=100), where REER = CPI / (official exchange rate * } \\
\text { CPI_USA) }\end{array}$ & $\begin{array}{l}\text { Easterly and } \mathrm{Yu} \\
(2000)\end{array}$ \\
\hline$R E D P$ & Deposit interest rate & World Bank (2000d) \\
\hline SPREAD & Spread between the deposit rate and the lending rate & World Bank (2000d) \\
\hline RDIF & $\begin{array}{l}\text { Deposit interest rate differential: domestic rate - US TBill } \\
\text { rate - } \% \text { change in exchange rate; where exchange rate = } \\
\text { local currency per dollar }\end{array}$ & $\begin{array}{l}\text { World Bank } \\
(2000 a) ; \text { World } \\
\text { Bank }(2000 d)\end{array}$ \\
\hline
\end{tabular}

\section{Financial development}

M3 Liquid liabilities as \% of GDP

CRED Credit to private sector as \% of GDP

World Bank (2000a)

World Bank (2000a) 
Table A2 (continued): Variables: Definitions and Sources

\begin{tabular}{lll}
\hline Variable & Definition & Source \\
\hline VI. Political and governance variables & \\
FREE & FREE $=$ & Freedom House (2001) \\
& $14-$ political rights index - civil liberties & \\
& index & \\
VOICE & Voice and accountability & Kaufman et al. $(1999)$ \\
GOVEF & Government efficiency & Kaufman et al. $(1999)$ \\
CONT & Risk contract repudiation* & Political Risk Services (2000) \\
COR & Corruption* & Political Risk Services (2000) \\
\hline
\end{tabular}

Note: * The indexes of contract repudiation and corruption are transformed as: 10 original value; so a high value indicates a worse situation. 
Table A3: Country Means of Regression Variables

\begin{tabular}{|c|c|c|c|c|c|c|c|c|c|c|c|c|c|}
\hline Country & $K F$ & $C D$ & $G R$ & $I N F L$ & $P B S$ & $R D I F$ & M3 & CRED & FREE & VOICE & GOVEF & $C O N T$ & $C O R$ \\
\hline Angola & 19.2 & 11.7 & -4.3 & 3028 & -16.8 & 131 & 33.6 & 4.2 & 1 & -1.00 & -1.39 & 6 & 7 \\
\hline Benin & -8.5 & 5.2 & 0.2 & 14.6 & 5.5 & -1.2 & 22.8 & 21.1 & 3 & 0.69 & -0.07 & NA & NA \\
\hline Burkina Faso & 2.5 & 2.7 & 1.2 & 3.2 & -9.3 & -1.3 & 15.8 & 13.4 & 4 & -0.21 & -0.21 & 5 & 6 \\
\hline Burundi & 5.6 & 5.3 & -2.3 & 9.7 & -2.1 & -1.5 & 18.6 & 14.0 & 1 & -1.29 & NA & NA & NA \\
\hline Cameroon & 3.9 & 5.0 & 1.1 & 9.1 & -2.3 & -0.2 & 19.5 & 21.0 & 2 & -0.70 & -0.64 & 4 & 7 \\
\hline C. A. R. & 1.4 & 3.9 & -1.5 & 3.6 & -5.7 & -0.5 & 17.5 & 11.2 & 2 & -0.04 & -0.05 & NA & NA \\
\hline Congo, DRC. & 1.9 & 5.1 & -3.9 & 1270 & NA & NA & 13.0 & 2.5 & 1 & -1.57 & -1.77 & 6 & 9 \\
\hline Congo, Rep. & -1.0 & 11.5 & 1.7 & 9.1 & -1.6 & -0.3 & 17.6 & 16.8 & 3 & -0.77 & -0.58 & 6 & 7 \\
\hline Côte d'Ivoire & 7.9 & 8.3 & -1.6 & 8.7 & 0.6 & -1.3 & 28.8 & 33.5 & 3 & -0.57 & -0.18 & 3 & 7 \\
\hline Ethiopia & 5.9 & 9.4 & -1.0 & 6.8 & -4.9 & 1.6 & 35.2 & 9.4 & 1 & -0.49 & -0.15 & 5 & 4 \\
\hline Gabon & 3.1 & 3.6 & -1.2 & 6.2 & -1.0 & 0.1 & 18.5 & 16.1 & 3 & -0.31 & -1.13 & 4 & 8 \\
\hline Ghana & 0.4 & 4.2 & -1.1 & 40.5 & -2.5 & 10.2 & 18.5 & 4.7 & 3 & -0.43 & -0.29 & 4 & 8 \\
\hline Guinea & 1.1 & 5.6 & 1.1 & NA & -1.8 & 13.6 & 7.1 & 4.2 & 1 & -0.87 & -0.03 & 6 & 7 \\
\hline Kenya & 0.5 & 4.5 & 0.8 & 13.9 & 6.1 & 1.1 & 32.0 & 27.7 & 3 & -0.70 & -0.90 & 4 & 7 \\
\hline Madagascar & 2.0 & 5.0 & -2.1 & 15.5 & -2.7 & 14.2 & 18.6 & 16.7 & 5 & 0.31 & -0.29 & 7 & 6 \\
\hline Malawi & 2.4 & 7.3 & 0.1 & 18.3 & -3.6 & 6.0 & 21.5 & 12.4 & 2 & 0.06 & -0.62 & 5 & 6 \\
\hline Mali & -2.0 & 5.7 & -0.4 & 4.9 & -1.8 & -1.3 & 19.2 & 17.0 & 3 & 0.41 & -0.05 & 7 & 9 \\
\hline Mauritania & 4.7 & 12.3 & -1.4 & 7.2 & 4.4 & -2.1 & 20.8 & 28.6 & 1 & -0.97 & NA & NA & NA \\
\hline Mauritius & 0.9 & 4.5 & 3.8 & 10.1 & 0.9 & 3.6 & 55.4 & 30.5 & 10 & 1.01 & 0.17 & NA & NA \\
\hline Mozambique & 12.2 & 17.0 & 1.5 & 46.7 & -2.9 & NA & 34.0 & 24.7 & 2 & -0.17 & -0.33 & 5 & 6 \\
\hline Niger & -4.9 & 3.1 & -2.4 & 6.6 & -2.6 & -1.3 & 14.0 & 12.2 & 2 & -0.74 & -1.39 & 5 & 6 \\
\hline Nigeria & 8.4 & 3.7 & -1.0 & 24.8 & 0.5 & 2.0 & 21.9 & 10.6 & 4 & -1.23 & -1.32 & 5 & 9 \\
\hline Rwanda & 4.3 & 2.7 & -0.4 & 9.0 & -4.1 & -1.4 & 14.7 & 6.0 & 2 & -1.17 & NA & NA & NA \\
\hline Senegal & -6.9 & 5.2 & -0.5 & 8.0 & -0.3 & -1.2 & 25.6 & 30.7 & 6 & -0.29 & 0.05 & 5 & 7 \\
\hline Sierra Leone & 4.7 & 4.6 & -1.5 & 41.9 & -9.4 & 10.3 & 16.0 & 4.8 & 3 & -1.62 & 0.01 & 6 & 8 \\
\hline Sudan & 1.6 & 6.7 & 0.0 & 45.9 & NA & -1.1 & 22.8 & 8.8 & 2 & -1.49 & -1.70 & 7 & 9 \\
\hline
\end{tabular}


Table A3 (continued): Country Means of Regression Variables

\begin{tabular}{|c|c|c|c|c|c|c|c|c|c|c|c|c|c|}
\hline Country & $K F$ & $C D$ & $G R$ & $I N F L$ & $P B S$ & $R D I F$ & M3 & CRED & $F R E E$ & VOICE & GOVEF & CONT & $C O R$ \\
\hline Togo & -5.8 & 7.5 & -1.4 & 7.8 & -0.7 & -1.2 & 34.6 & 23.7 & 2 & -1.05 & -0.37 & 5 & 8 \\
\hline Uganda & 3.1 & 5.2 & 2.0 & 71.6 & -2.4 & 11.0 & 11.2 & 3.6 & 3 & -0.52 & -0.25 & 6 & 8 \\
\hline Zambia & 12.0 & 11.6 & -2.2 & 79.6 & -0.7 & 1.0 & 29.5 & 15.0 & 5 & -0.04 & -0.40 & 6 & 8 \\
\hline Zimbabwe & 5.2 & 3.3 & 0.6 & 16.4 & -2.3 & 4.4 & 22.4 & 22.8 & 4 & -0.67 & -1.13 & 5 & 7 \\
\hline Sample $^{\mathrm{a}}$ & 2.9 & 6.4 & -0.5 & 20.2 & -2.9 & 1.5 & 22.7 & 15.6 & 2.9 & -0.55 & -0.56 & 5.3 & 7.3 \\
\hline
\end{tabular}

$\mathrm{KF}=$ capital flight $/ \mathrm{GDP} ; \mathrm{CD}=$ change in debt $/ \mathrm{GDP} ; \mathrm{GR}=$ growth of per capita GDP; INFL = inflation; PBS = primary budget surplus $/ \mathrm{GDP} ; \mathrm{RDIF}=$ deposit rate $-\mathrm{TBill}$ rate; $\mathrm{M} 3=\mathrm{M} 3 / \mathrm{GDP} ; \mathrm{CRED}=$ credit to the private sector/GDP; FREE $=$ political freedom $(=14-$ political rights - civil liberties $) ; \mathrm{VOICE}=$ voice and accountability; GOVEF $=$ government effectiveness; $\mathrm{CONT}=$ risk of contract repudiation; $\mathrm{COR}=$ corruption .

${ }^{a}$ For each variable, the sample average (simple averages, not weighted) is computed by considering only countries that are included in the relevant regression sample (see notes to Tables $3 \mathrm{a}, 3 \mathrm{~b}, 4 \mathrm{a}$, and $4 \mathrm{~b}$ ). 